Amsterdam Expeditions to the West Indian Islands, Report 48*

\title{
HARPACTICOID COPEPODS FROM THE WEST INDIAN ISLANDS: LAOPHONTIDAE (COPEPODA, HARPACTICOIDA)
}

\author{
by \\ FRANK FIERS \\ Koninklijk Belgisch Instituut voor Natuurwetenschappen, Recent Invertebrates Section, \\ Vautierstraat 29, B-1040 Brussels, Belgium
}

\begin{abstract}
The present paper deals exclusively with the species of the family Laophontidae found in samples gathered during several expeditions of the University of Amsterdam to the West Indies. Four new species belonging to different genera are described. Two new species and Laophonte adriatica are assigned to a new genus: Lipomelum $\mathbf{n}$. gen. Furthermore, additional information on seven other laophontids is given.
\end{abstract}

\section{RÉSUMÉ}

Cet article traite exclusivement des espèces de la famille des Laophontidae, récoltées pendant les différentes expéditions de l'Université d'Amsterdam aux Indes Occidentales. Quatre nouvelles espèces appartenant à différentes genres sont décrites. Deux nouvelles espèces et Laophonte adriatica sont réunis dans un nouveau genre: Lipomelum $\mathbf{n}$. gen. De plus, des informations additionnelles sont données pour sept autres espèces.

\section{INTRODUCTION}

This second paper on the harpacticoid copepods sampled during the West Indian Expeditions of the University of Amsterdam deals exclusively with the family Laophontidae. The material yielded 13 species of which 6 are new to science.

In previous publications on the copepods from the West Indian area, 12 species of the family Laophontidae were recorded. These species are listed in table I. Laophonte mississippiensis Herrick, 1887 (Mobile Bay, Alabama, U.S.A.), a doubtful species considered as incertae sedis (Lang, 1948) is not included in table I.

- Report 47 has been published in Bijdragen tot de Dierkunde, 55 (2): 331-426 (1985).

\section{TABLE I}

Previous records (taxonomically updated) of Laophontidae in the West Indies. The capitals in front of the authors' names refer to the map in fig. 1.

A: Chappuis \& Delamare Deboutteville (1956)

Bimini, Bahamas

- Paralaophonte brevirostris (Claus)

- Paralaophonte zimmeri Van Douwe

- Klieonychocamptoides arenicola (Chappuis \& Delamare Deboutteville)

- Afrolaophonte renaudi (Chappuis \& Delamare Debouttevile)

B: Coull (1970)

Kingston Harbor, Jamaica

- Paralaophonte brevirostris f. (Willey)

Black Rock and Belairs, Barbados

- Paralaophonte brevirostris f. (Willey)

C: Coull (1971)

St. Thomas, U.S. Virgin Islands

- Laophonte cornuta Philippi

- Laophonte spinicauda (Vervoort)

- Paralaophonte brevirostris f. fissirostris (Willey)

D: Cottarelli (1977)

Champoton village, Mexico

- Mexicolaophonte arganoi Cottarelli

E: Mielke (1982)

Isla Nalunega, Panama

- Laophontina triarticulata Coull \& Zo

Isla Naos, Panama**

- Laophontina ? spec. (= Mexicolaophonte spec.)

F: Wilson (1936)

Progresso, Mexico

- Onychocamptus mohammed (Blanchard \& Richard)

G: Yeatman (1976)

Montego Bay, Jamaica

- Paralaophonte congenera (Sars)

H: Fiers (1984a)

Grande-Terre, Guadeloupe

- Laophonte spinicauda (Vervoort)

** Isla Naos, situated along the East Pacific coast, is of interest in the discussion of $M$. arganoi and the generic status of Laophontina? spec. 
In this list two species, Paralaophonte brevirostris and $P$. zimmeri, need special attention. Both species are listed without description or illustrations by Chappuis \& Delamare Deboutteville (1956). As species discrimination in the genus Paralaophonte is not an easy task and since the material studied by Chappuis is not available, I am inclined to consider both as misidentifications.
The present material comprises only three species mentioned or described in previous papers: Laophonte cornuta, L. spinicauda, and Mexicolaophonte arganoi. Four other species: Esola longicauda, Klieonychocamptoides itoi, Echinolaophonte horrida, and Quinquelaophonte quinquespinosa are reported from the West Indies for the first time.

The material is treated as described in a former publication (Fiers, 1984b).

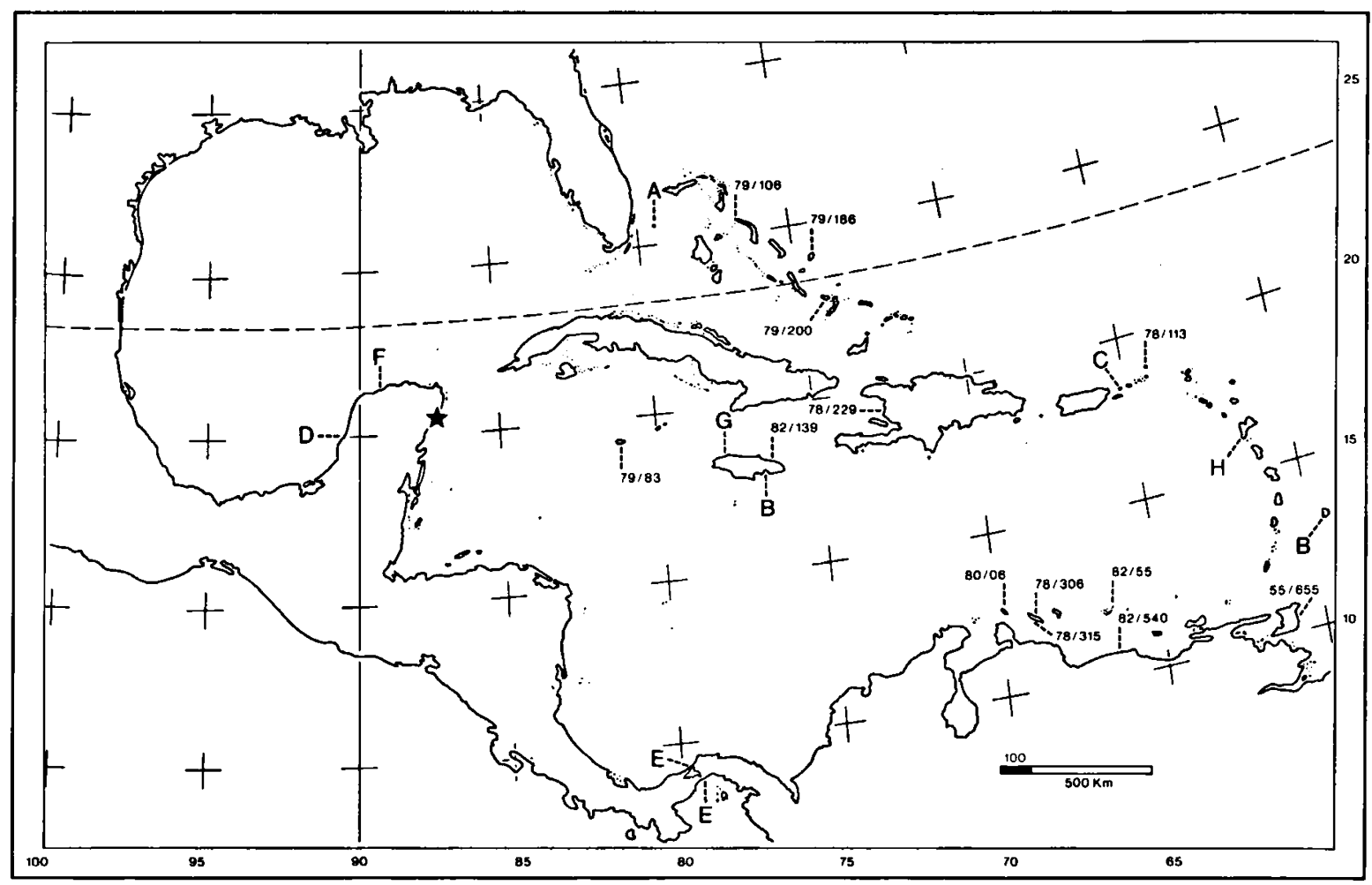

Fig. 1. Map of the West Indies. Capitals indicate previous records (see table I), the numerals indicate the stations dealt with in this paper. The asterisk locates an additional sample, taken at Cozumel (Mexico), which is now under study.

\section{SYSTEMATICS}

\section{Laophonte cornuta Philippi, 1840}

Material. - Amsterdam Expeditions to the West Indian Islands, sta. 79-83. Gayman Islands, Grand Cayman: South coast, W. of Savannah, John Bodden's Bay $\left(19^{\circ} 16^{\prime} 21^{\prime \prime} \mathrm{N} 81^{\circ} 15^{\prime} 20^{\prime \prime} \mathrm{W}\right)$, washed from sublittoral, coarse coral sand (depth ca. $0.3 \mathrm{~m}$ ), behind a barrier reef, 29 Nov. 1979. Two females, two males, and one juvenile C IV.
Sta. 82-55. Venezuela, Roques Archipelago: Dos Mosquises, South Island, East shore, method KaramanChappuis near the end of the airstrip $\left(11^{\circ} 48^{\prime} 14^{\prime \prime} \mathrm{N}\right.$ $\left.66^{\circ} 53^{\prime} 25^{\prime \prime} \mathrm{W}\right)$, coarse sand in the tidal zone; chlorinity $22,592 \mathrm{mg} / \mathrm{l}$, temp. $26.5^{\circ} \mathrm{C}, 5 \mathrm{March} 1982$. One adult female.

Sta. 82-540. Venezuela (mainland): mouth of Río Todasana (ca. $15 \mathrm{~km}$ from Carnao, on the road to Los Caracas $\left(10^{\circ} 37^{\circ} 47^{\wedge} \mathrm{N} 66^{\circ} 27^{\prime} 16^{\wedge} \mathrm{W}\right)$, method KaramanChappuis in coarse sand of the beach (intertidal), chlorinity $32,192 \mathrm{mg} / \mathrm{l}, 6 \mathrm{March} 1982$. One female, three 
males, one juvenile male $\mathrm{C} \mathrm{V}$, two juvenile females $\mathrm{C} \mathrm{V}$, and one juvenile $C$ IV.

Remarks. - In each sample, specimens with a normal opercular spine and specimens with a modified spine occur together. In comparison, in specimens from the North and South Atlantic, the Mediterrean Sea, and the Indian and Pacific Oceans, I never observed such variability. Lang (1965) dealing with Californian specimens, considered this variability as an indication of an "intense evolution process". In the following pages two other species of the cornuta group are described, one of which very closely related to $L$. cornuta.

\section{Laophonte expansa $n$. sp.}

(Figs. 2-4)

Material. - Amsterdam Expeditions to the West Indian Islands, sta. 78-113. British Virgin Islands, Anegada: Deep Bay (= E. of Loblolly Bay, $18^{\circ} 44^{\prime} 20^{\prime \prime} \mathrm{N}$ $68^{\circ} 18^{\prime} 18^{\prime \prime} \mathrm{W}$ ), interstitial of marine coarse sand in the littoral zone behind the barrier reef, 23 April 1978. One female (holotype) dissected and mounted on four slides, labeled WIAE $8 \mathrm{a}, \mathrm{b}, \mathrm{c}$, and $\mathrm{d}$.

Etymology. - The specific name expansa, from the Latin expandere (= to extend), refers to the strongly extended pleurites.

\section{Description}

Female (holotype). - Habitus (figs. 2a-e): length, including rostrum and furcal rami, 520 $\mu \mathrm{m}$; cephalothorax with curved lateral margins; lateral sides with a deep incision in the posterior third of the cephalothorax; integument of cephalothorax pitted with a remarkable triangular pattern formed by large smooth rectangular fields; posterior margin of cephalothorax smooth; thoracic segments with deep pleurites; integument of thoracic segments covered with a dense pattern of strong spinules; genital segments fused, having a strongly dented transversal ridge over the entire dorsal surface; abdominal segments with laterally extended margins; dorsum of the abdominal segments ornamented as the thoracic segments; ventral side of these segments with integumental lines; posterior ventral margin of the second genital segment smooth and of the first ab- dominal segment with long hairs and with strong teeth on the last abdominal segment; anal segment with strong blunt spines along the lateral margin; anal operculum almost straight and with rounded teeth along the posterior margin; furcal rami two and a half times as long as wide; outer and inner margin laterally extended and furnished with blunt spinules; there are subapical and median lateral setae; inner apical seta short; no outer apical seta; principal apical seta smooth; ventral side of the rami with integumental lines.

Antennule (fig. 3a) four-segmented; first, second and third segments with a pitted integument; first segment with an irregular knob; second segment with a sharp curved hook and a small blunt one; third segment with four strong rounded extensions; aesthetasc implanted on the distal edge of the third segment and measuring $120 \mu \mathrm{m}$; ultimate segment short, bearing setae articulating on a basal part.

Antenna (fig. 3e) with allobasis; inner margin ribbed; outer margin with small spinules and a short seta; endopodite with two subapical setae and one subapical spine; distal margin of the endopodite with a short and strongly curved spine, two strongly armed spines and three setae; exopodite with four subequal armed spines.

Mandible (fig. 3d) with a long and strong gnathobasis; pars molaris slightly developed and rounded; basis of coxa cylindrical; exopodite obsolete and represented as a seta; endopodite represented by three setae; apical seta densely feathered.

Maxillule identical to that of Laophonte cornuta.

Maxilla (fig. 3b): syncoxa densely clothed with large hairs along the external margin; two short rows of small teeth on the surface; proximal endite represented by a seta; median and distal endite cylindrical and prolonged in a strongly armed spine and bearing two setae; basis typically extended, bearing one seta; exopodite and endopodite obsolete, both represented as setae; both maxillae of this specimen were densely overgrown with algae so that the exact number of endopodal and ex- 


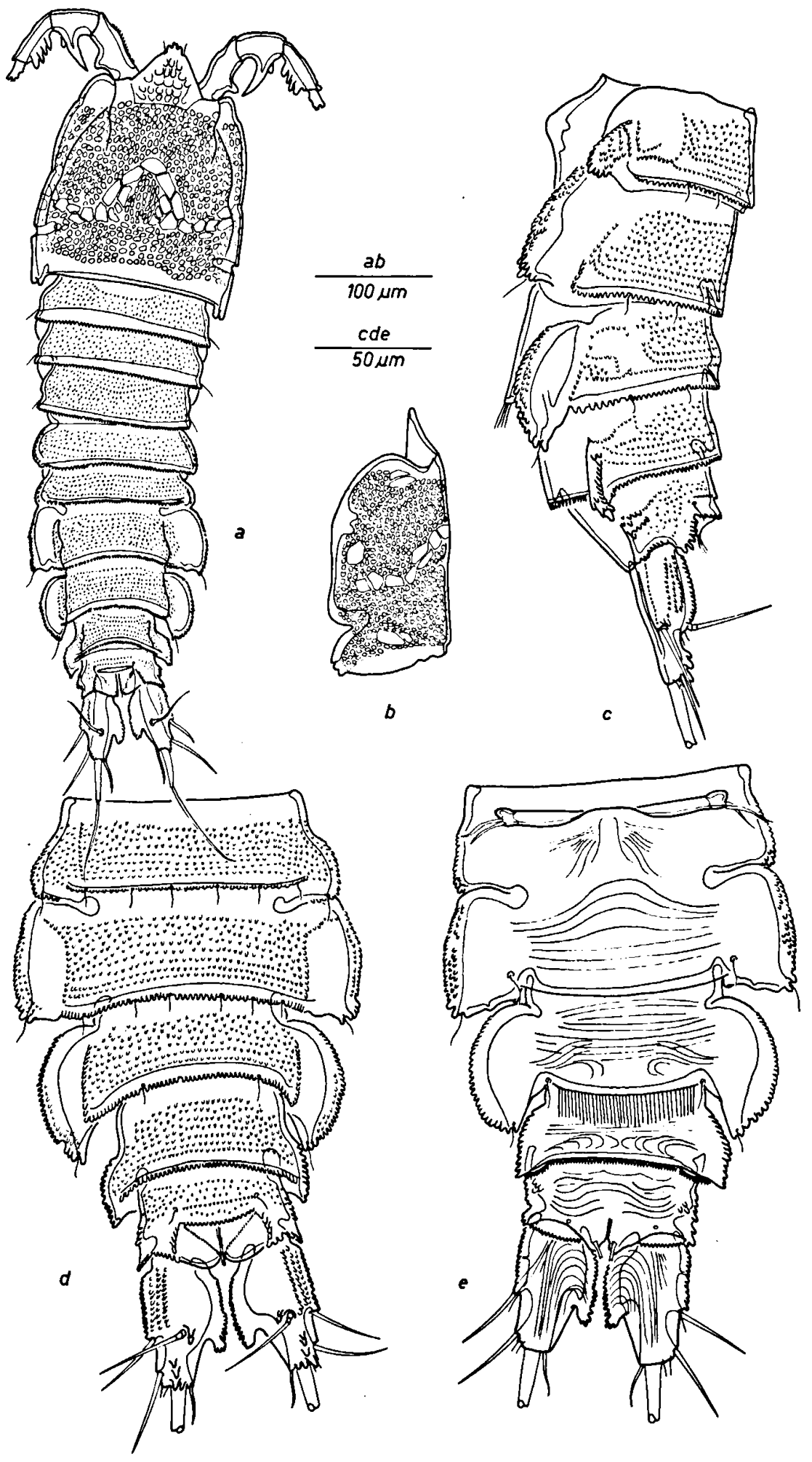

Fig. 2. Laophonte expansa n. sp.: a, habitus; b, cephalothorax in lateral view; c, abdomen in lateral view; d, abdomen in dorsal view; e, abdomen in ventral view. 


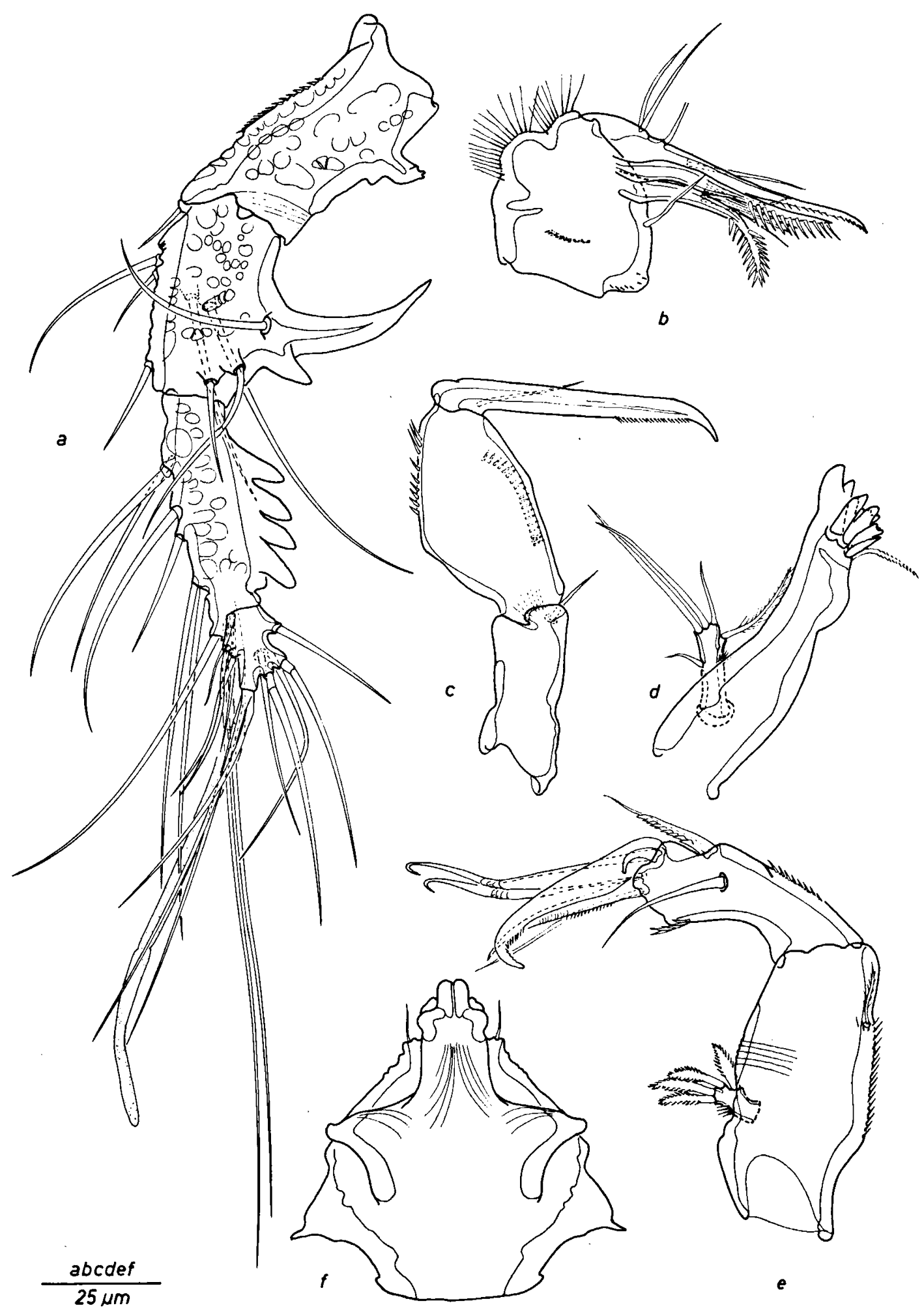

Fig. 3. Laophonte expansa n. sp.: a, antennule; b, maxilla; c, maxilliped; d, mandible; e, antenna; f, rostrum. 


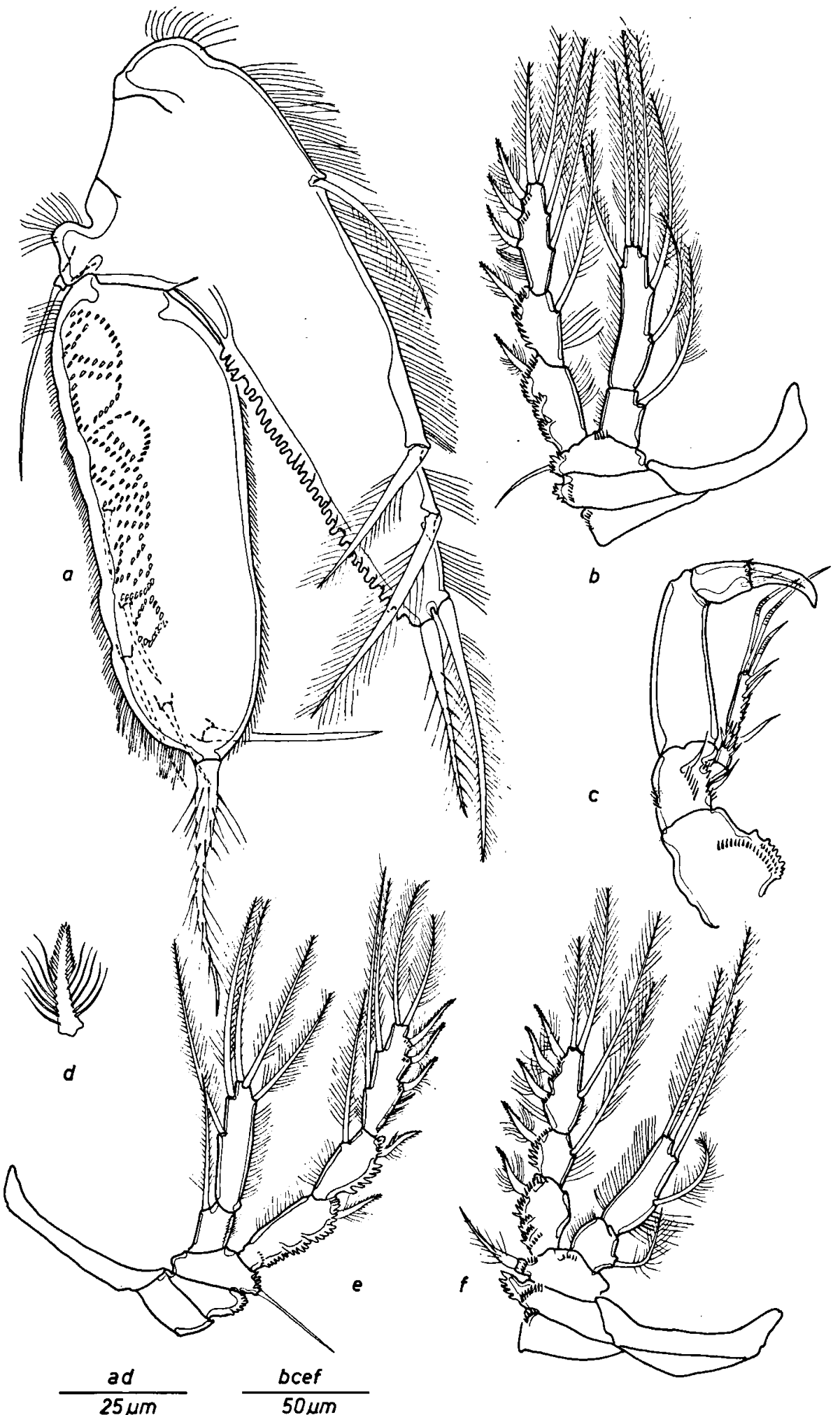

Fig. 4. Laophonte expansa n. sp.: a, P5; b, P3; c, P1; d, exopodal spine; e, P4; f, P2. 
opodal setae could not be observed with certainty.

Maxilliped (fig. 3c): basis with an apical row of hairs and one apical seta; first endopodal segment with an external and an internal row of strong teeth; endopodal claw armed and bearing one small seta.

P1 (fig. 4c): coxa with three rows of strong teeth along the external margin; basis with two setae and furnished with rows of long spinules; exopodite two-segmented; first segment short; second segment twice as long as the preceding one and bearing five setae; first endopodal segment with smooth surface; second endopodal segment with a distal row of four small teeth and one minute seta; endopodal claw strong.

P2-P4 (figs. 4b, d, e, and f): external margin of the exopodal segments projecting into rather blunt tooth-shaped processes comparable with those on the third antennular segment; outer spines of all exopodal segments armed with spinules in the distal half and furnished with long setules in the proximal half; exopodites three-segmented, endopodites two-segmented; setal formula shown in table II.

TABlE II

Setal formula of Laophonte expansa $\mathrm{n}$. sp.

\begin{tabular}{cccc}
\hline & P2 & P3 & P4 \\
\hline exo & $0-1-123$ & $0-1-223$ & $0-1-223$ \\
end & $1-220$ & $1-321$ & $1-221$ \\
\hline
\end{tabular}

P5 (fig. 4a): baseoendopodite large, tapering towards the distal margin and bearing five setae; inner margin with blunt spine-shaped extensions; exopodite long, ovate and bearing five smooth lateral setae and one feathered distal seta; margins of the exopodite covered with small hairs; outer surface with a pattern of small spinules.

Male. - Unknown.

Discussion. - Laophonte expansa n. sp. belongs to the cornuta group of the genus Laophonte. This new species is easily distinguishable from the three other species of the group by the remarkable body shape and the special furcal rami. Apart from these discriminating features, $L$. expansa $n$. sp. shows some astonishing structures. The lateral incision of the cephalothorax is, to my knowledge, not comparable with any known structure found in other laophontids. The exopodal spines are quite remarkable as well. It is possible that $L$. expansa $n$. sp. requires a special generic status in the future.

Five species, including $L$. expansa $n$. sp. and $L$. plana n. sp., are now attributed to the cornuta group of the genus Laophonte. Without any doubt this species group deserves a generic status. At this moment however, the erection of a new genus for the remaining species would not contribute to taxonomic stability. When removing the cornuta group, including the typespecies of the genus Laophonte, away from the genus Laophonte, it is necessary to find a proper diagnosis for all the remaining species. However, the remaining group is very heterogeneous and it cannot be defined by one single relevant generic diagnosis. Therefore the cornuta group must tentatively be held in the genus Laophonte sensu Lang (1948), until other materials (partially in study) will allow a thorough revision of the genus Laophonte.

\section{Laophonte plana $n$. sp.}

(Figs. 5-6)

Material. - Amsterdam Expeditions to the West Indian Islands, sta. 78-315. Netherlands Antilles, Curaçao: Piscadera Bay, at the first buoy, in washings of the top layer of coarse coral sand collected by SCUBA divers at a depth of $-4 \mathrm{~m}$, estimated position $12^{\circ} 07^{\prime} 42^{\prime \prime} \mathrm{N}$ $68^{\circ} 58^{\prime} 18^{\prime \prime} \mathrm{W}, 22$ May 1978. One female (holotype, dissected and mounted on four slides, labelled WIAE 3a, $b, c$, and d).

Etymology. - The specific name plana, from the Latin (= flat), alludes to the flattened body shape of the species.

\section{Description}

Female (holotype). - Habitus (figs. $5 \mathrm{a}, \mathrm{b}$, and c): length, including rostrum and furcal rami, $750 \mu \mathrm{m}$; body dorsoventrally depressed; cephalothorax tapering anteriorly; thoracic and abdominal segments tapering posteriorly; 


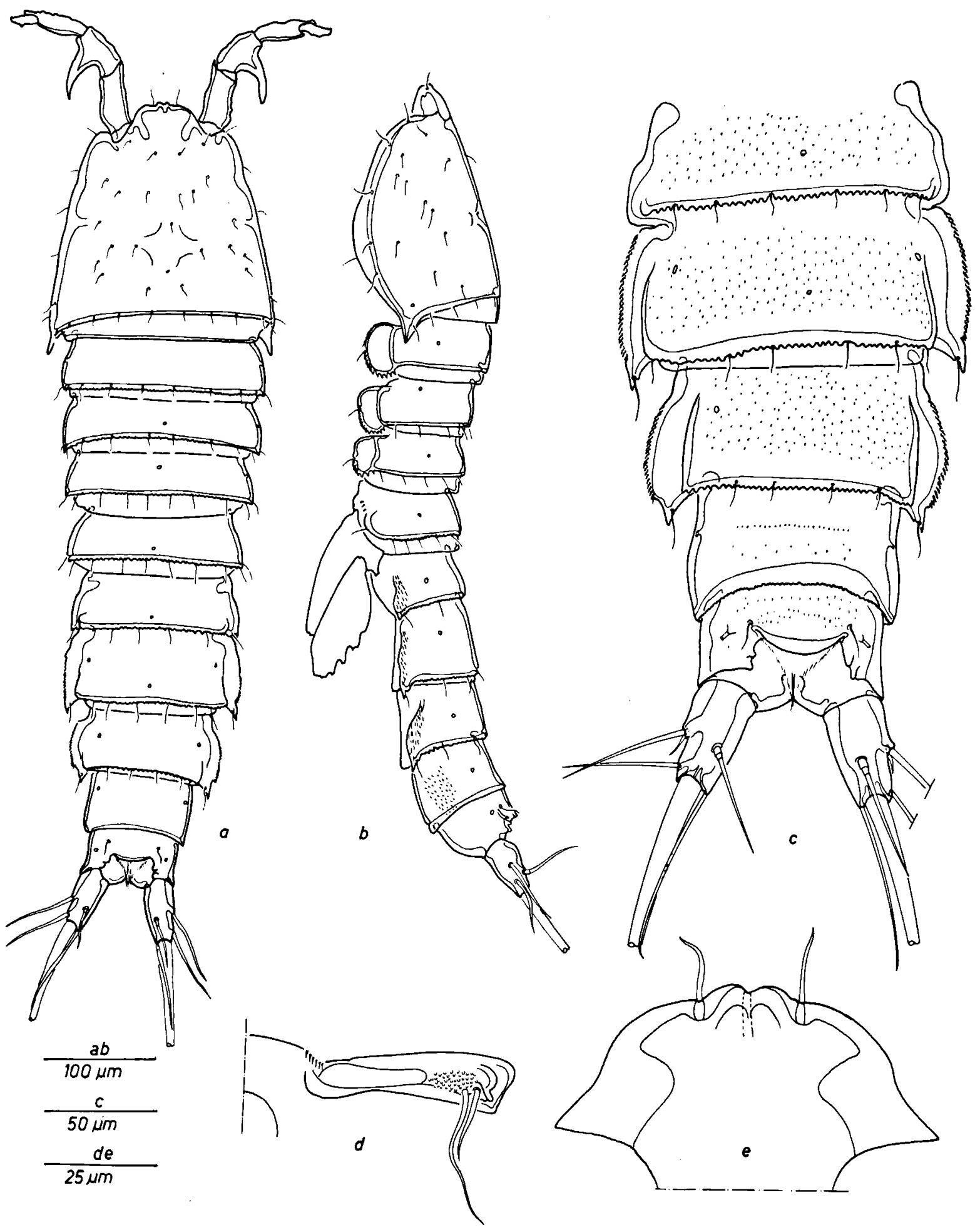

Fig. 5. Laophonte plana n. sp.: a, habitus; b, habitus in lateral view; c, abdomen in dorsal view; $d$, genital field; e, rostrum. 
posteroventral edge of cephalothorax prolonged in a posteriorly directed sharp extension; genital segments fused, fusion indicated by a transversal thick dorsal band; second genital segment and first abdominal one extending laterally; extensions furnished with small spinules; anal segment with a smooth operculum; integument of cephalothorax smooth; thoracic and abdominal segments covered with a sparse pattern of spinules; ventral surface of the genital and abdominal segments smooth.

Genital field (fig. 5d) bearing two smooth setae and showing a small field covered with small tubercles.

Rostrum (fig. 5e) fused with the cephalothorax with convex margins and a slightly prominent bifid apex.

Furcal rami (fig. 5c) about twice as long as wide; conical, tapering posteriad; dorsal setae articulating on two basal parts; two external setae; outer apical seta very small and fused with the principal one; inner apical seta remarkably long.

Antennule (fig. 6a) four-segmented; first segment with a small rounded knob; second segment with a strongly curved hook; penultimate segment with parallel rows of spinules along one side and bearing the aesthetasc; number and shape of the setae as in Laophonte cornuta.

Antenna, mandible, maxillule and maxilla as in Laophonte cornuta.

Maxilliped (fig. 6d): basis with two rows of long spinules and a subapically implanted feathered seta; first endopodal segment with a straight inner margin and a convex outer one; endopodal claw armed with very minute teeth and one short seta.

P1 (fig. 6b): praecoxa triangular; coxa with several rows of small teeth near and along the outer margin; basis bearing two setae and two rows of spinules; exopodite two-segmented; first exopodal segment with one, second segment with five setae; first endopodal segment robust without integumental structures; second segment also smooth and bearing a short unarmed claw and a small seta.

Setal formula and shape of P2, P3 and P4 as in Laophonte cornuta.
P5 (fig. 6c): baseoendopodite prominent, furnished with long spinules along the margins and bearing three inner and two apical setae; exopodite ovate, reaching beyond the apical margin of the baseoendopodite; exopodal margin set with spinules and having six setae.

Male. - Unknown.

Discussion. - Laophonte plana n. sp. undoubtedly belongs to the cornuta group of the genus Laophonte. Within this group, $L$. plana $\mathbf{n}$. sp. resembles most $L$. cornuta. This new species differs from the latter in the dorsoventrally depressed body, the posteriorly extended edge of the cephalothorax, the setation of the furcal rami and the proportional lengths of the baseoendopodite and the exopodite of the P5.

As mentioned above, four species have been assigned to the cornuta group since Lang's monograph (1948) appeared. Therefore a key to the species is presented here. The key is based on female characteristics but it will be useful for discriminating the male specimens as well.

\section{KEY TO THE SPECIES OF THE CORNUTA GROUP}

1. Antennule, second segment with a strong hook-shaped process; exopodite of the antenna with subequal setae ............................................ 2

- Antennule, second segment without a hook-shaped process; exopodite of the antenna with unequal setae; female with a reticulated ventral side of the genital segments ................. Laophonte adduensis Sewell

2. Furcal rami cylindrical or slightly tapering posteriad; cephalothorax without integumental structures; third antennular segment without large extensions ..... 3

- Furcal rami expanded along the inner margin; cephalothorax with a pattern of integumental structures and with an important lateral incision; third antennular segment with strong and blunt extensions Laophonte expansa n. sp.

3. Body dorsoventrally depressed; cephalothorax extended posteriorly; furcal rami about twice as long as wide .......................... Laophonte plana n. sp.

- Body fusiform; cephalothorax not extended posteriorly; furcal rami three times as long as wide

4. Integument of the thoracic and abdominal segments with blunt spinules; apical margin of the baseoendopodite reaching just beyond the middle of the exopodite; three outer spines on the third exopodal segments of P2-P4

Laophonte comuta Philippi 


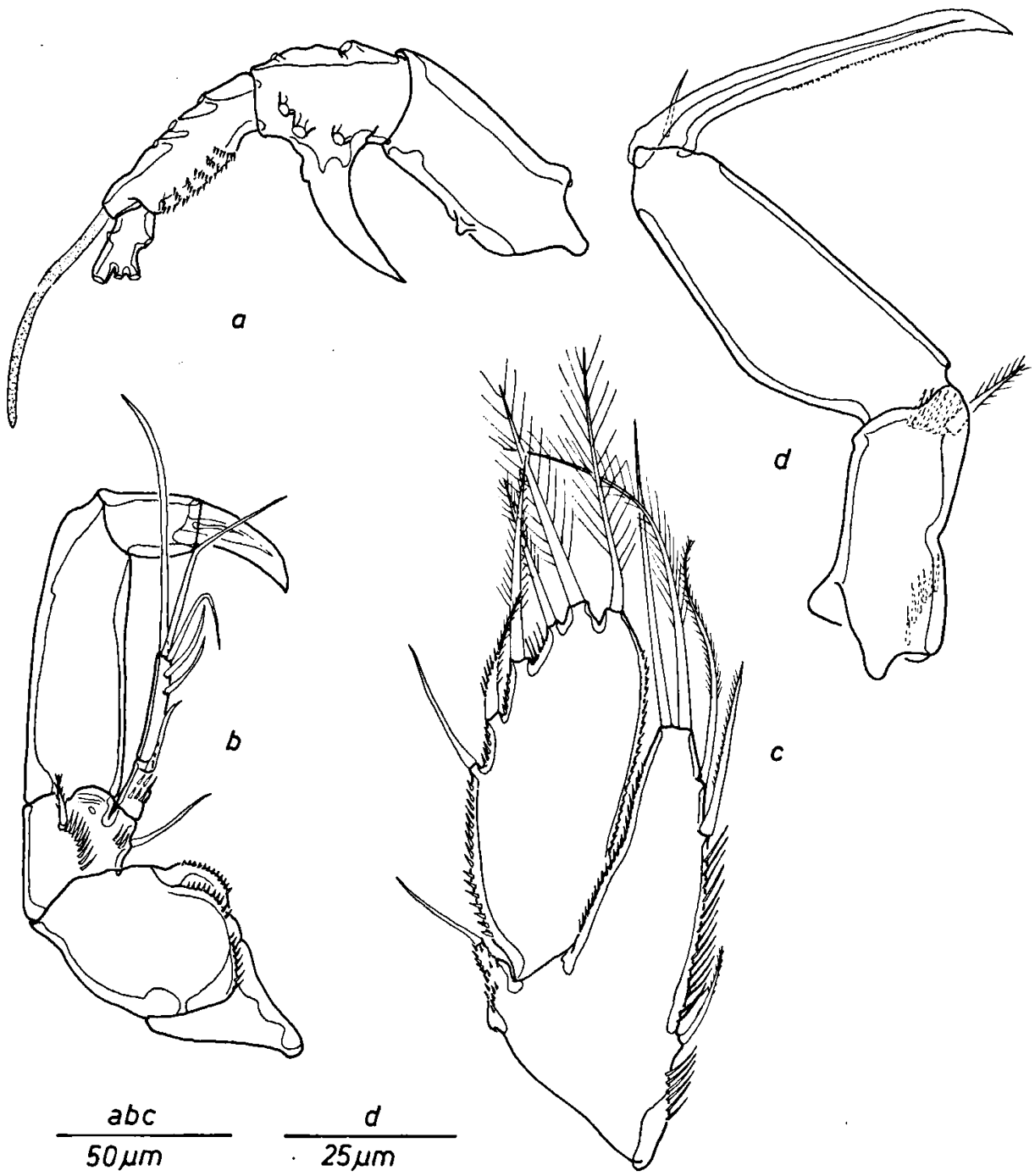

Fig. 6. Laophonte plana n. sp.: a, antennule; b, P1; c, P5; d, maxilliped.

- Integument of the thoracic and abdominal segments furnished with rows of small hairs; apical margin of the baseoendopodite reaching almost to the apical margin of the exopodite; two outer spines on the third exopodal segments of P2-P4 .. Laophonte ciliata Noodt

\section{Laophonte spinicauda (Vervoort, 1964)}

Material. - Amsterdam Expeditions to the West Indian Islands, sta. 78-113. British Virgin Islands, Anegada: Deep Bay. More information under $L$. expansa n. sp. One adult male.

Sta. 82-540. Venezuela (mainland): $15 \mathrm{~km}$ from Carnao. More information under Laophonte cornuta. Two adult males and one adult female.
Remarks. - Up to now $L$. spinicauda has been recorded from three wide-spread localities: the Caroline Islands (Vervoort, 1964, typelocality), St. Thomas in the U.S. Virgin Islands (Coull, 1971) and Guadeloupe (Fiers, 1984a). This species occurs also in samples from the Red Sea, the Maldivean Archipelago and the northern coast of Papua New Guinea (all unpublished data). L. spinicauda has neither been found in the Mediterranean Sea, nor in the Atlantic Ocean. Therefore, L. spinicauda should not be regarded as a circumtropical species but as an Indo-Pacific fauna element in the West Indies. 
Quinquelaophonte quinquespinosa (Sewell, 1924)

Material. - Amsterdam Expeditions to the West Indian Islands, sta. 79-106. Bayamas, Eleuthera: Caribbean side of the island, N. of Marions Bluff, anchihaline pool (rocks, sand) in the coral terrace $\left(25^{\circ} 01^{\prime} 42^{\prime \prime} \mathrm{N}\right.$ $\left.76^{\circ} 08^{\prime} 30^{\prime \prime} \mathrm{W}\right)$, chlorinity $928 \mathrm{mg} / \mathrm{l}, 8$ Nov. 1979. Four adult females and one adult male.

Sta. 79-117. Same island, N. of Gregory Town, shallow well (water table at $31 / 2 \mathrm{~m}$, water depth $1 / 2 \mathrm{~m}$ ) $\left(25^{\circ} 23^{\prime} 39^{\prime \prime} \mathrm{N} 76^{\circ} 33^{\prime} 30^{\prime \prime} \mathrm{W}\right)$, polluted, chlorinity 528 $\mathrm{mg} / \mathrm{l}$, temp. $25.3^{\circ} \mathrm{C}, 9$ Nov. 1979 . One adult male.

Sta. 79-200. Bahamas, Crooked Island: McKays Bluff Sea Cave $\left(22^{\circ} 45^{\prime} 22^{\prime \prime} \mathrm{N} 74^{\circ} 10^{\prime} 31^{\prime \prime} \mathrm{W}\right)$, half-dark, washed from sand just above the waterline (low tide), chlorinity $23,620 \mathrm{mg} / \mathrm{l}, 27$ Nov. 1979. One adult female.

Remarks. - The specimens here dealt with belong undoubtedly to the species $Q$. quinquespinosa, as redescribed by Wells \& McKenzie (1973) and Wells et al. (1982). However, the specimens show a very interesting feature. The inner distal edge of the first endopodal segment of the third leg bears a few long and fragile hairs. These hairs reach beyond the apical margin of the second segment but sometimes they are hardly visible. The position and the shape of these hairs show great resemblance to the inner "seta" of $Q$. parasigmoides Bozic, 1964.

It is clear that through this correction $Q$. parasigmoides falls within the range of variability of $Q$. quinquespinosa and should therefore be considered synonymous with the latter.

\section{Paralaophonte echinata n. sp.}

(Figs. 7-9)

Material. - Amsterdam Expeditions to the West Indian Islands, sta. 79-186. BaHAmas, San Salvador Island: Dixon Hill Lighthouse Cave (anchihaline) (24.05' $44^{\prime \prime} \mathrm{N}$ $74^{\circ} 27^{\prime} 07^{\prime \prime} \mathrm{W}$ ), completely dark, tidal influence, chlorinity $21,264 \mathrm{mg} / \mathrm{l}$, temp. $24.8^{\circ} \mathrm{C}$; hand net between rocks, loamy, 23 Nov. 1979. One female (holotype, dissected and mounted on two slides, labelled WIAE 25a and 25b), one adult male (paratype, dissected and mounted on a single slide, labelled WIAE 26).

Sta. 82-02. Venezuela, Tortuga Island: western extremity, E. of Punta Arenas $\left(10^{\circ} 55^{\prime} 29^{\prime \prime} \mathrm{N}\right.$ $\left.65^{\circ} 25^{\prime} 05^{\prime \prime} \mathrm{W}\right)$, method Karaman-Chappuis, ca. $50 \mathrm{~cm}$ above the waterline, rather coarse sand, chlorinity 23,928 $\mathrm{mg} / \mathrm{l}, 17 \mathrm{Feb}$. 1982. One adult female, in alcohol.
Etymology. - The specific name echinata, from the Latin (= spinous), refers to the dense pattern of small spinules on the cephalothorax, the pleurotergites and the antennule.

\section{Description}

Female (holotype). - Habitus (figs. 7a, b and c): length, measured from the tip of the rostrum to the posterior margin of the furcal rami, 520 $\mu \mathrm{m}$; largest width at the level of the posterior margin of the cephalothorax; body somewhat depressed; lateral margins furnished with long hairs; integument entirely covered with an irregular pattern of small spinules; posterior margin smooth and ornamented with long hairs; thoracic segments with large pleurites extended in lateral direction; integument of the pleurotergites with an irregular pattern of spinules; posterior margins furnished with stronger spinules and long hairs; genital segments fused, fusion indicated by a transversal row of strong spinules; lateral margins extended and covered with long teeth; anteroventral region of the fused genital segments with integumental lines, posteroventral region with transverse rows of strong teeth; ventral and dorsal sides of the abdominal segments spinulose; posteroventral margin of the segments with teeth, except for the genital segments, which carry long hairs.

Genital field as illustrated (fig. 9e).

Rostrum smooth and fused with cephalothorax; tip only slightly prominent and not bilobate.

Furcal rami cylindrical and twice as long as wide; inner margin with two parallel rows of long spinules; external margin with two setae; one dorsal seta, articulating on two basal parts; principal apical setae armed and not fused; inner apical seta small.

Antennule (fig. 8c) six-segmented; first to fourth segments densely covered with small spinules and strong teeth along the margins; aesthetasc implanted on the fourth segment; penultimate and ultimate segment with a smooth surface.

Antenna and mouthparts as in Paralaophonte problematica Mielke. 


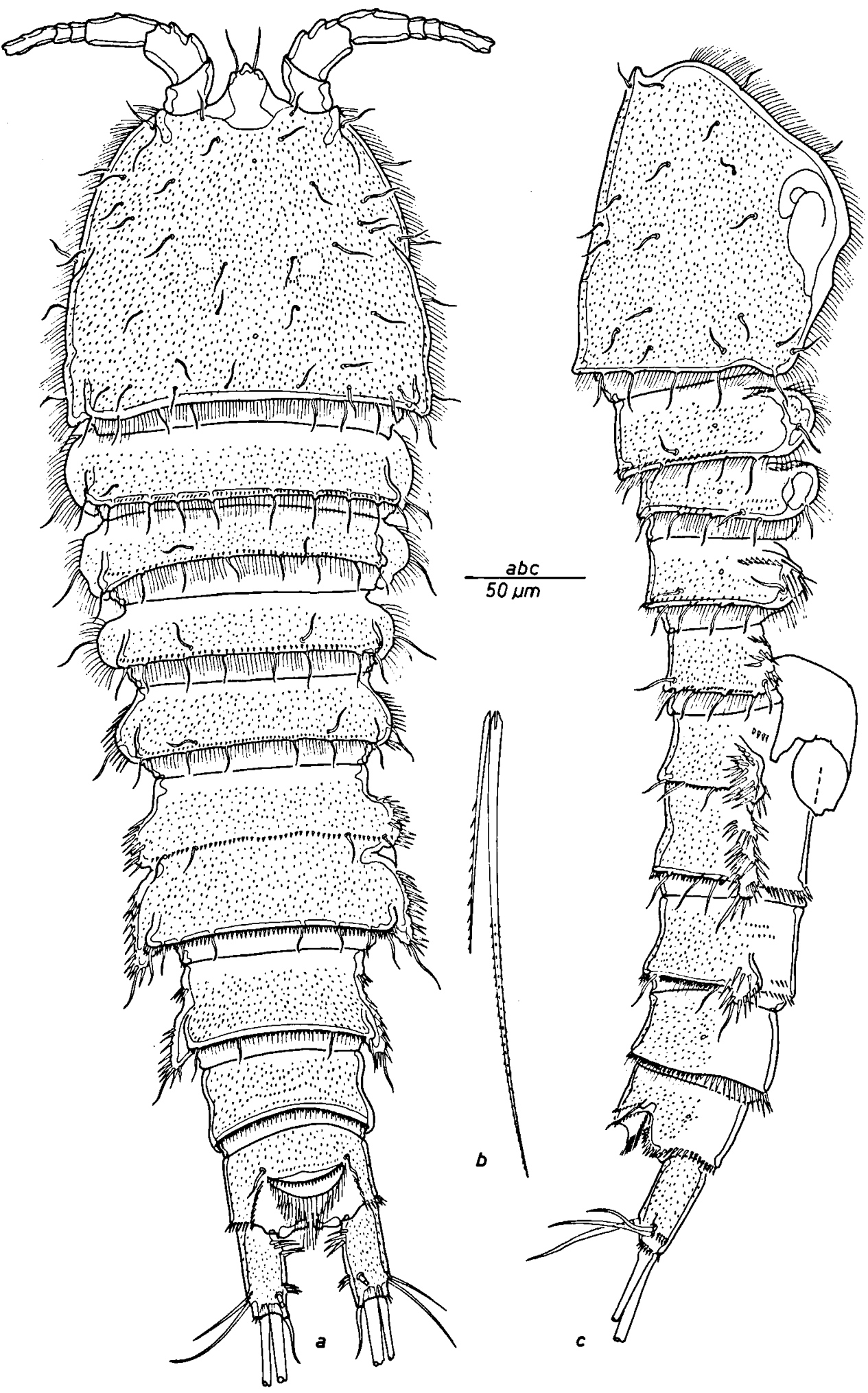

Fig. 7. Paralaophonte echinata n. sp.: a, habitus of female; b, left apical furcal setae; c, habitus of female in lateral view. 


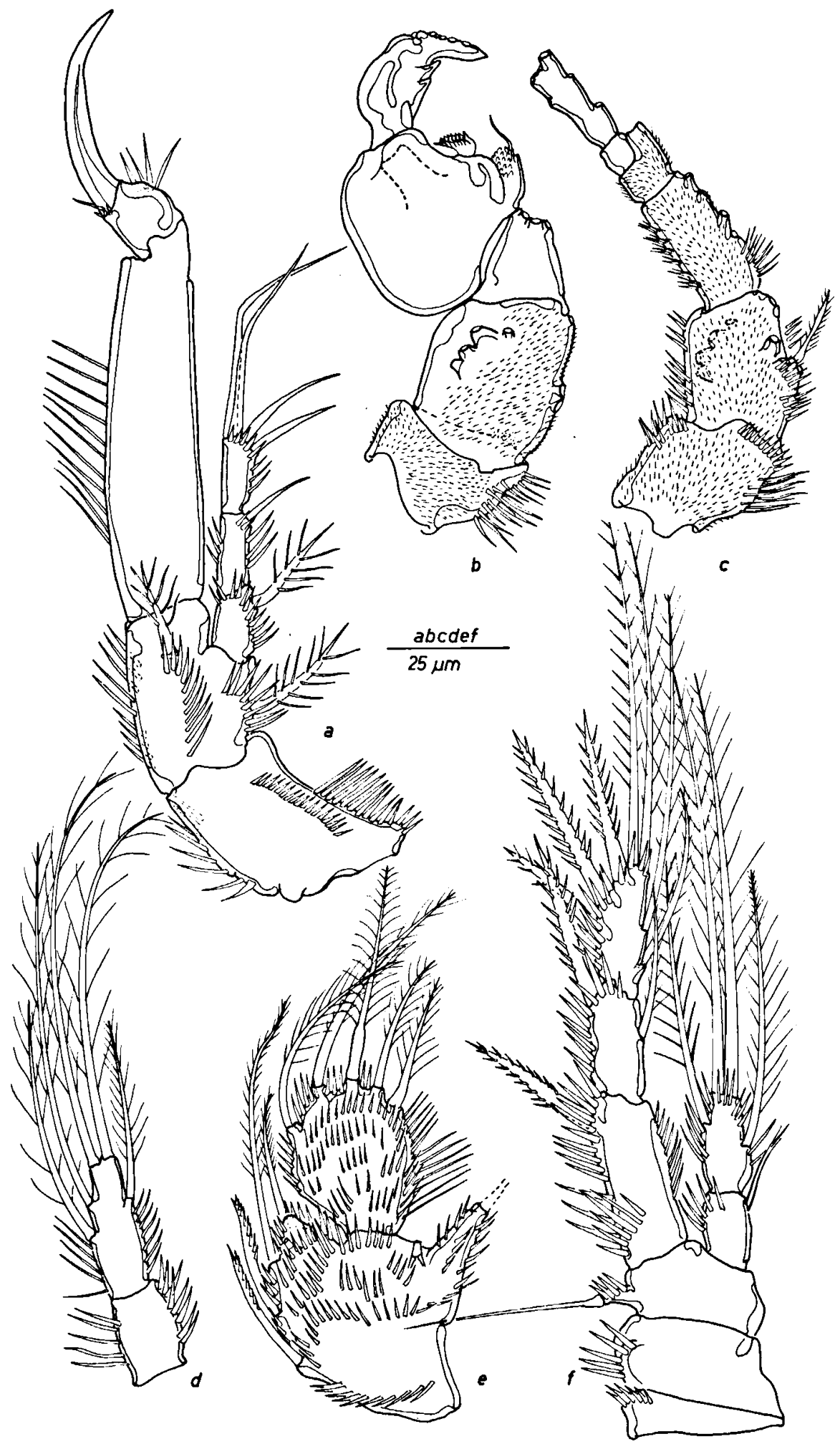

Fig. 8. Paralaophonte echinata n. sp.: a, P1; b, antennule of the male; c, antennule of the female; d, endopodite P3 of the female; e, P5 of the female; $f, P 4$ of the male. 


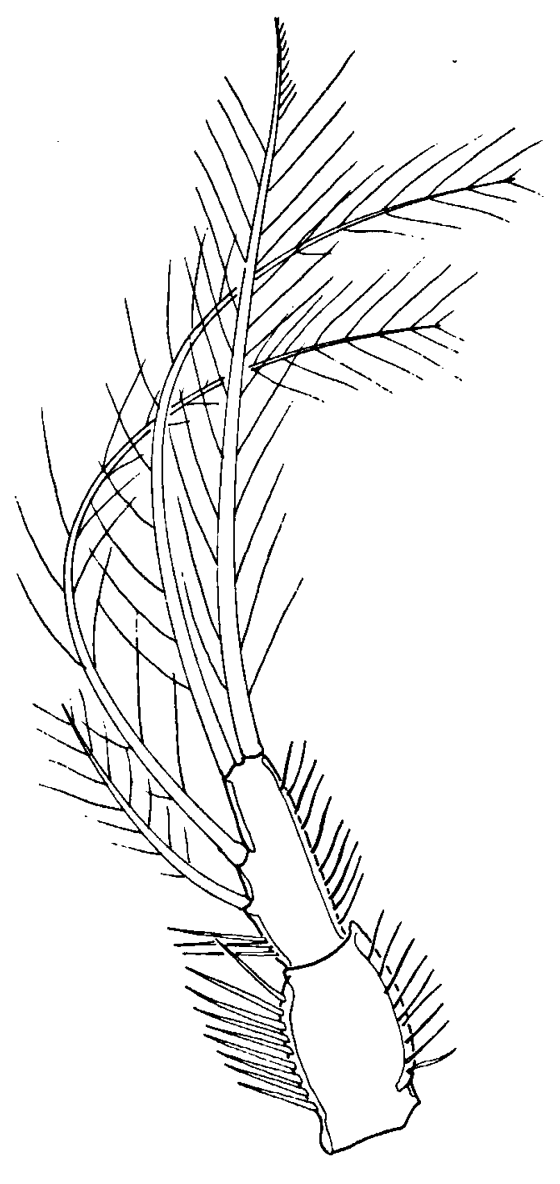

a
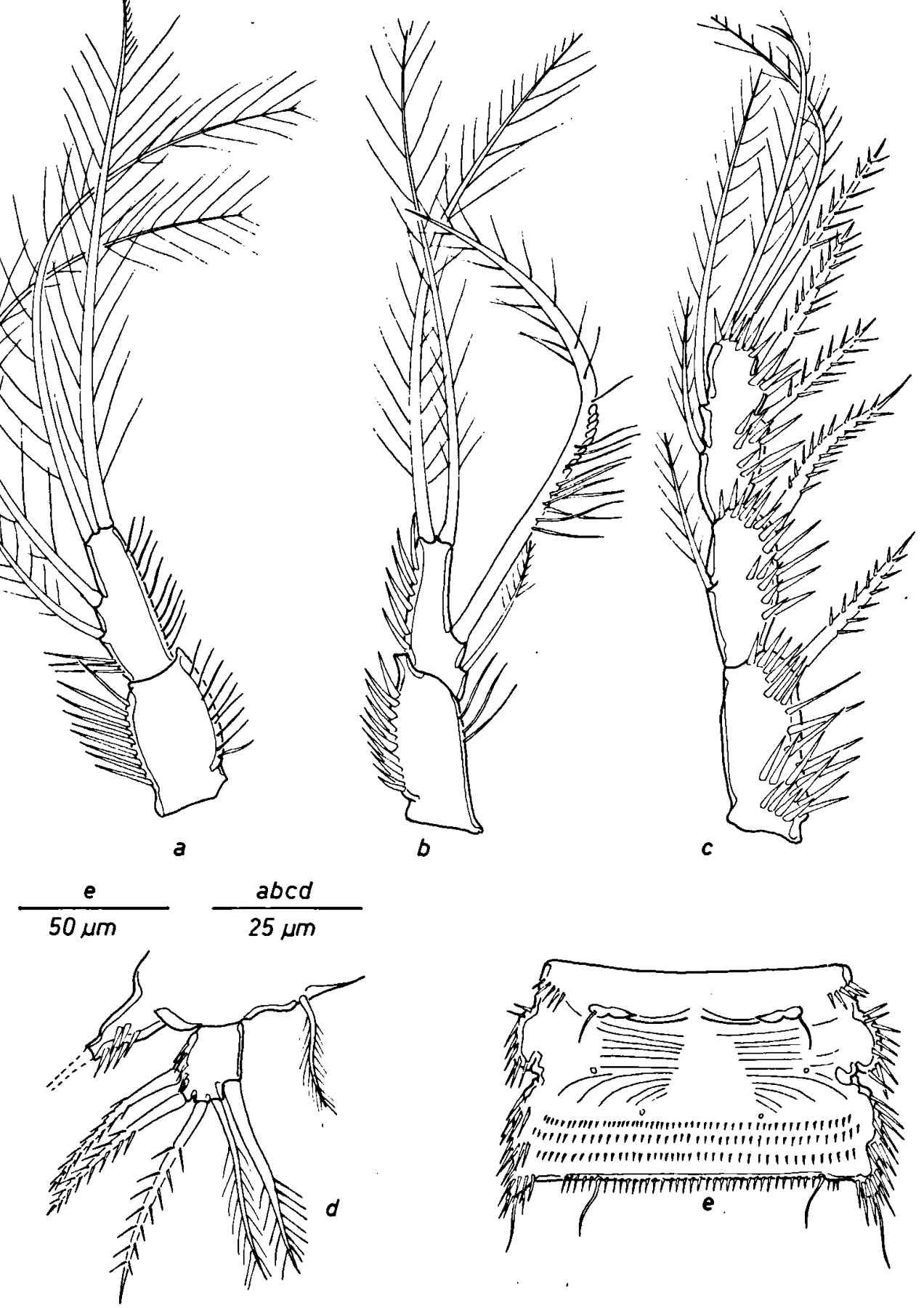

Fig. 9. Paralaophonte echinata n. sp.: a, endopodite P2 of the female; b, endopodite P2 of the male; c, exopodite P4 of the female; $d, P 5$ of the male; e, genital segments of the female in ventral view. 
P1 (fig. 8a): coxa, basis and exopodite as in $P$. problematica; first endopodal segment with a single row of long hairs and about 4.5 times as long as wide; endopodal claw unarmed.

Setal formula of P2-P4 shown in table III.

TABLE III

Setal formula of Paralaophonte echinata n. sp.

\begin{tabular}{lccc}
\hline & P2 & P3 & P4 \\
\hline exo & $0-1-123$ & $0-1-223$ & $0-1-223$ \\
end & $0-220$ & $0-221$ & $0-121$ \\
\hline
\end{tabular}

P2 (fig. 9a): protopodite and exopodite as in $P$. problematica; endopodal setae all with long setules except for a small distal part of the outermost seta.

P3 (fig. 8d): protopodite and exopodite as in L. problematica; endopodite without an inner notch; all setae with long setules.

P4 (fig. 9c): protopodite, exopodite and endopodite as in $P$. problematica, except for the inner proximal seta of the third exopodal segment which is much longer.

P5 (fig. 8e): baseoendopodite with four setae; exopodite with five setae; general appearance as in $P$. problematica, but with a more rounded exopodite.

Male. - Habitus as the female; length $420 \mu \mathrm{m}$; genital segments not fused and not extended laterally; integumental structures as in the female.

Antennule (fig. 8b) five-segmented and geniculated; first and second segment almost as in the female; inner margin of the fourth segment with a "cushion" covered with blunt spinules and a strongly armed spine; fifth segment curved, having strong and sharp extensions.

Mouthparts and P1 as in the female.

P2 (fig. 9b): exopodite as in the female; endopodite two-segmented; first segment with a large pore near the inner distal edge; second segment with four setae; proximal inner seta strongly developed with setules in the proximal half, strong and blunt spinules in the middle of the stem and fragile setules in the distal half; both apical setae as in the female.

$\mathrm{P} 3$ as in $P$. problematica.

P4 (fig. 8f) almost the same as P4 of the female.

P5 (fig. 9d): baseoendopodite fused with the segment, bearing one short seta; exopodite rather square, having five setae; inner exopodal seta strong; the three outermost setae with strong setules and the inner apical seta with fragile hairs.

P6 as in $P$. problematica.

Discussion. - Paralaophonte echinata n. sp. seems to be related to $P$. problematica Mielke, 1982 in several respects. The former differs mainly from the latter in the long furcal rami, the round exopodite of the fifth leg and the shape of the endopodal segments. The new species shows also some resemblance to $P$. gracilipes (Brady, 1910), an insufficiently known species. $P$. echinata n. sp., however, can be easily distinguished from $P$. gracilipes by the strongly dimorphic third leg of the male and the six-segmented antennule of the female.

As already stressed by Mielke (1981) and Wells et al. (1982), recognition of relationships between the species and the several species groups of the genus Paralaophonte is rather difficult. Up to now, species groups have been distinguished mainly by the shape of the dimorphic characteristics of the legs. The importance of these features is probably overestimated because several reduction lines seem to have evolved independently. Only a detailed comparison of the species of the genus can throw some light on the relationships within the genus.

\section{Esola longicauda Edwards, 1891}

Material. - Amsterdam Expeditions to the West Indian Islands, sta. 79-200. Bahamas, Crooked Island: McKays Bluff Sea Cave (further details under Quinqueloophonte quinquespinosa). One damaged female, in alcohol.

Echinolaophonte horrida (Norman, 1876)

Material. - Amsterdam Expeditions to the West Indian Islands, sta. 79-186. BAHAMAS, San Salvador Island: 
Dixon Hill Lighthouse Cave (further details under Paralaophonte echinata). One adult female, in alcohol.

Remarks. - Echinolaophonte horrida is a typical boreal species known from many localities along the European and North American coasts. Three dubious records, all unverifiable, are known from the Mediterranean Sea (Brian, 1923; Van Douwe, 1929; and Jakubisiak, 1933).

The presence of $E$. horrida in Bahamian caves emphasizes the rather complex biogeographical history of this area. As already pointed out by Yeatman (1962) on the basis of hydrological characteristics of the area and the Gulf Stream, the occurrence in those caves is probably not of a recent date. $E$. horrida seems to be a representative of a relict fauna derived from a North Atlantic stock.

During Pleistocene glaciations, boreal waters influenced at least the northern part of the West Indies. It could be that in this area a boreal fauna was established, which later disappeared or survived in marginal habitats, such as the Bahamian caves, $E$. horrida then being one of these survivors.

Further analysis, however, of the so-called ubiquitous species occurring in Bahamian and West Indian caves, is necessary to corroborate this working hypothesis.

\section{Lipomelum n. gen.}

Diagnosis. - Habitus cylindrical or depressed; rostrum prominent and fused with the cephalothorax; genital segments fused, fusion marked dorsally; antennule six-segmented with a small process on the second segment; antenna with allobasis; exopodite onesegmented, bearing one feathered seta, two armed spines and one short and smooth seta.

P1 with three-segmented exopodite; endopodite with a claw and a small seta; P2-P4 with three-segmented exopodites and twosegmented endopodites. P5 baseoendopodite and exopodite bearing five setae; exopodite rounded, reaching beyond the apical margin of the baseoendopodite.
Male with a geniculated antennule; P1-P4 as in the female except for some modifications of the exopodite of the P4. P5: baseoendopodite fused with the segment, without setae; exopodite bearing four setae. P6 represented by a seta and a spine.

Type-species. - Lipomelum heteromelum $\mathbf{n}$. sp., here designated.

Etymology. - The generic name is formed

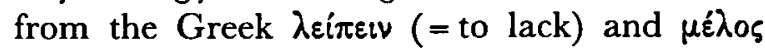
(=leg), and alludes to the absence of sexual dimorphism of the endopodites of the male; gender neutral.

\section{Lipomelum heteromelum n. sp.}

(Figs. 10-12)

Material. - Amsterdam Expeditions to the West Indian Islands, sta. 82-540. Venezuela (mainland): mouth of Río Todasana (further details under Laophonte cornuta). Three females, two males, and one juvenile female $\mathrm{C} \mathrm{V}$. One female dissected (holotype, mounted on two slides, labelled WIAE 27a and 27b), one male dissected (paratype, mounted on two slides, labelled WIAE 28a and 28b), and one female (paratype, dissected, slide 29); remaining paratypes preserved in alcohol.

Sta. 79-200. Bahamas, Crooked Island: McKays Bluff Sea Cave (further details under Quinquelaophonte quinquespinosa). One juvenile (C IV).

Sta. 80-06. Netherlands Antilles, Aruba: Playa Indieco Cara p'Abao at Andicuri $\left(12^{\circ} 32^{\prime} 28^{\prime \prime} \mathrm{N}\right.$ $\left.69^{\circ} 56^{\prime} 54^{\prime \prime} \mathrm{W}\right)$, interstitia of gravel of an exposed beach, chlorinity $24,380 \mathrm{mg} / \mathrm{l}$, temp. $30.0^{\circ} \mathrm{C}, 22$ May 1980 . One female, dissected and mounted on two slides, labelled WIAE 21a and $b$.

Etymology. - The specific name heteromelum,

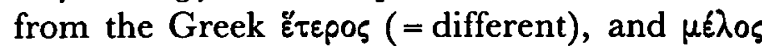
(=leg), alludes to the sexual differences in the P4 exopodites.

\section{Description}

Female (holotype). - Habitus (figs. 10a and b): length, including rostrum and furcal rami, $640 \mu \mathrm{m}$; body cylindrical; cephalothorax tapering in anterior direction; thoracic and abdominal segments tapering slightly towards the anal segment; genital segments fused, fusion marked dorsally by a thick band; first and second abdominal segment only slightly extended 
laterally; integument of the cephalothorax, pleurotergites and abdominal segments densely covered with small spinules; posterior margin of the cephalothorax smooth; posterior margins of the thoracic and abdominal segments ornamented with spinules; anal segment with a convex anal operculum furnished with teeth; ventral side of the genital segments without integumental structures; ventral sides of the abdominal and anal segments covered with transverse rows of spinules.

Rostrum (fig. 10d) prominent and fused with the cephalothorax; integument smooth, except for a tuft of spinules between the sensillae.

Furcal rami cylindrical, about 1.5 times as long as wide; inner margin with two rows of long spinules; surface covered with small spinules; two lateral setae; dorsal seta articulating on two basal parts; both principal setae developed and not fused; inner apical seta small.

Antennule (fig. 10c) six-segmented; each segment with strong spinules, except for the penultimate and ultimate segment; second segment with a sharp, but small process; aesthetasc implanted on the fourth segment.

Antenna (fig. 11a): allobasis with a subapically implanted seta; exopodite as in the generic diagnosis; endopodal segment with two subapical spines, four apical setae and two apical spines.

Mandible (fig. 10f): gnathobasis with pars molaris; mandibular palp with one feathered seta and three slender setae, representing the vestigial rami.

Maxillule (fig. 12c): arthrite with five ornamented (spinules not figured) spines and two setae; coxa and basis confluent; two coxal setae; basis with three setae and a row of strong spinules; exopodite present, bearing two setae; endopodite absent, represented by two setae.

Maxilla (damaged during dissection) having two endites each bearing three setae; basis prolonged and armed distally, bearing two setae; endopodite represented by a single seta.

Maxilliped (fig. 10e): basis with rows of strong spinules and one seta; first endopodal segment with convex margins having a transversal and a longitudinal row of spinules; endopodal claw smooth, bearing a short seta.

P1 (fig. 11b): coxa and basis densely covered with rows of long teeth; basis with one inner and one outer spine; exopodite threesegmented, ultimate segment with four setae; first endopodal segment about four times as long as wide, furnished with a row of long hairs along the inner margin; second endopodal segment having an unarmed claw and a small seta.

P2-P4 (figs. 11c-e): three-segmented exopodites and two-segmented endopodites; setal formula shown in table IV; praecoxae, coxae and basis with rows of strong spinules; third exopodal segment of P4 with four spines implanted on the straight apical edge.

\section{TABLE IV}

Setal formula of Lipomelum heteromelum n. gen., n. sp.

\begin{tabular}{cccc}
\hline & P2 & P3 & P4 \\
\hline exo & $0-0-023$ & $0-0-023$ & $0-0-022$ \\
end & $0-120$ & $0-120$ & $0-120$ \\
\hline
\end{tabular}

P5 (fig. 12a): baseoendopodite with five adorned spines; surface covered with rows of spinules; exopodite having five smooth (all?) setae; shape almost round; integument covered with spinules.

Male. - Habitus as the female; genital segments not fused; length $480 \mu \mathrm{m}$; ventral side of the abdominal segments (fig. 12f) covered with transverse rows of spinules.

Antennule (fig. 12b) six-segmented; first and second segment as in the female; third to sixth segment geniculate.

Mouthparts, P1, P2 and P3 as in the female.

P4 (fig. 11f): third exopodal segment with an inner apical smooth seta and a spine; outer margin with two spines; other features as in the female.

P5 (fig. 12d): baseoendopodite fused with the segment; baseoendopodite of the left side with a seta, right baseoendopodite without; exopodite square, bearing four setae and covered with spinules. 


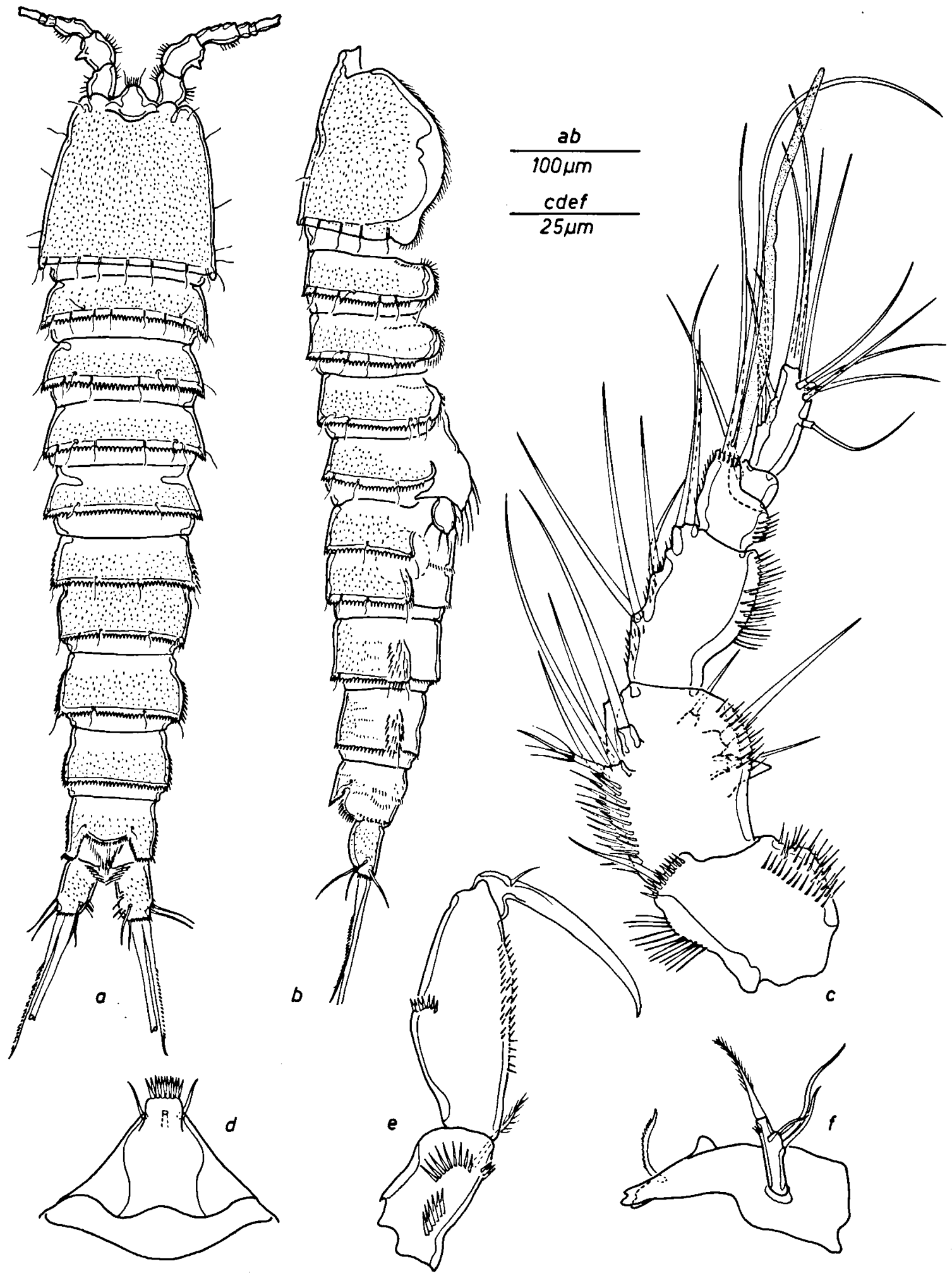

Fig. 10. Lipomelum heteromelum n. gen., n. sp.: a, habitus of the female; b, habitus of the female in lateral view; $c$, antennule; $d$, rostrum; e, maxilliped; $f$, mandible. 


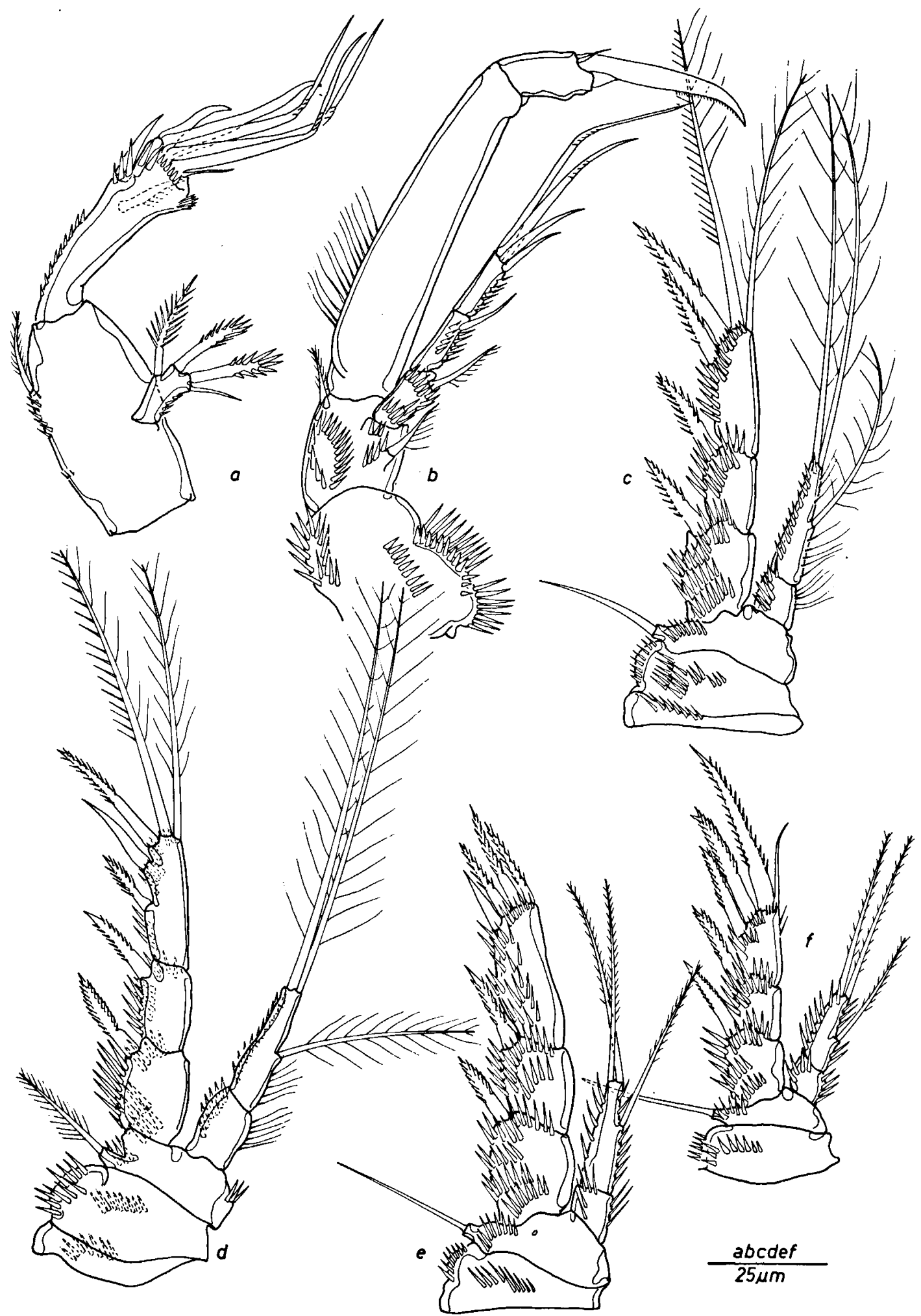

Fig. 11. Lipomelum heteromelum n. gen., n. sp.: a, antenna; b, P1; c, P2; d, P3; e, P4 of the female; f, P4 of the male. 

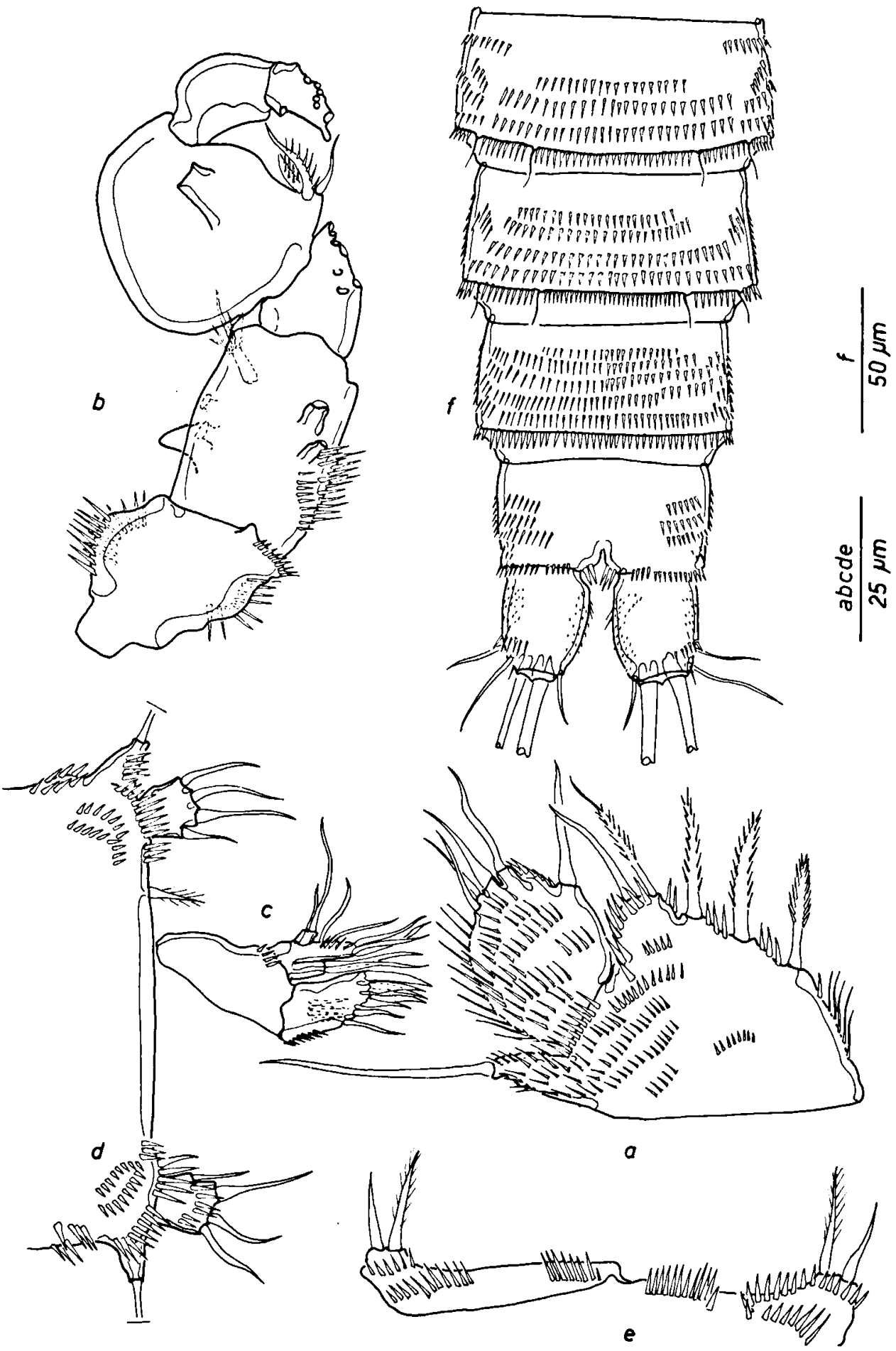

Fig. 12. Lipomelum heteromelum n. gen., n. sp.: a, P5 of the female; b, antennule of the male; c, maxillule; d, P5 of the male; e, P6 of the male; $f$, abdomen of the male in ventral view. 
P6 (fig. 12e): left P6 with two rows of spinules and bearing two strong setae; right P6 entirely fused with the segment.

Variability. - The above-described male bears a seta on the left baseoendopodite. This seems to be aberrant because the second male specimen and the males of Lipomelum adriaticum (see below) have no baseoendopodal setae.

Discussion. - In the present paper, three species: Lipomelum heteromelum n. sp., Lipomelum variabile n. sp., and Laophonte adriatica Petkovski, 1955, are attributed to the genus Lipomelum n. gen. The species of this genus share characteristics that clearly differentiate them from the other genera of the Laophontinae. The absence, in the male, of a modified endopodite, and a baseoendopodite fused with the segment and without setae, are unique within the Laophontinae. These features make it rather difficult to impossible to establish relationships with the other genera.

In the description of Laophonte adriatica, Petkovski (1955) suspected affinities with Laophonte denticornis T. Scott, 1894 and L. nordgaardi Sars, 1908. The relationship of Lipomelum n. gen. with the denticornis group of the genus Laophonte, however, now seems dubious. The species of the denticornis group all have distinct secondary sexual characters, as well as a free, setiferous, baseoendopodite. Other features such as the exopodite of the antenna and the shape of the endopodal segments of the legs clearly differentiate the denticornis group from the species of Lipomelum $\mathbf{n}$. gen.

Because Laophonte adriatica is re-allocated here to the genus Lipomelum n. gen., the new combination should be indicated as Lipomelum adriaticum (Petkovski, 1955).

\section{Lipomelum variabile $n$. sp.}

(Figs. 13-14)

Material. - Amsterdam Expeditions to the West Indian Islands, sta. 82-139. Jamaica: Discovery Bay, mouth of Rio Secco, on the sea side of a bar of coarse sand and gravel which closes off the dry river $\left(18^{\circ} 27^{\prime} 21^{\prime \prime} \mathrm{N}\right.$ $\left.77^{\circ} 24^{\prime} 34^{\prime \prime} \mathrm{W}\right)$; method Karaman-Chappuis, just above the zone reached by the waves, marine, 29 March 1982.
Four adult females, one of which, the holotype, dissected and mounted on three slides, labelled WIAE $30 \mathrm{a}, \mathrm{b}$, and c; the remaining three paratypes preserved in alcohol.

Sta. 78-306. Netherlands Antilles, Curaçao: Boca Tabla $\left(12^{\circ} 22^{\prime} 19^{\prime \prime} \mathrm{N} \quad 68^{\circ} 06^{\prime} 49^{\prime \prime} \mathrm{W}\right), \quad$ Bou-Rouch biophreatical pump in coarse, loamy sand near the waterline (marine), frequently reached by the waves, 19 May 1978. Four adult females, one dissected (on two slides, labelled WIAE $31 \mathrm{a}$ and $\mathrm{b}$ ).

Sta. 80-06. Netherlands Antilles, Aruba: Playa Indieco Cara p'Abao (further details see under Lipomelum heteromelum). Three adult females, one dissected (on two slides, labelled WIAE $32 a$ and $b$ ).

Etymology. - The specific name variabile, from the Latin (=variable), alludes to the variable setal formula of the legs P2-P4.

\section{Description}

Female (holotype). - Habitus (figs. 13b and c): length, including furcal rami and rostrum, $510 \mu \mathrm{m}$; body depressed; cephalothorax broad, slightly tapering anteriorly; lateral margins furnished with long hairs; integument smooth; thoracic and abdominal segments tapering towards the anal segment; thoracic and abdominal segments covered with small spinules; posterior margin of the cephalothorax and the other somites set with spinules; genital segments fused, fusion marked with a dorsal transversal band, furnished with teeth; ventral side of the genital segments with one transverse row of spinules; ventral side of the abdominal segments with several transverse rows of teeth; posteroventral margins with long spinules; anal operculum rounded and set with strong teeth.

Rostrum fused with the cephalothorax, bearing a tuft of strong spinules between the sensillae; integument smooth.

Furcal rami almost twice as long as wide; inner margin with two rows of strong teeth; integument spinulose; two lateral setae and one dorsal seta, articulating on two basal parts; principal apical setae developed, not fused; inner apical seta short and smooth.

Antennule (fig. 14a): six-segmented; first, second and third segment with long teeth along their margins; second segment with a blunt extension; aesthetasc implanted on the fourth segment. 


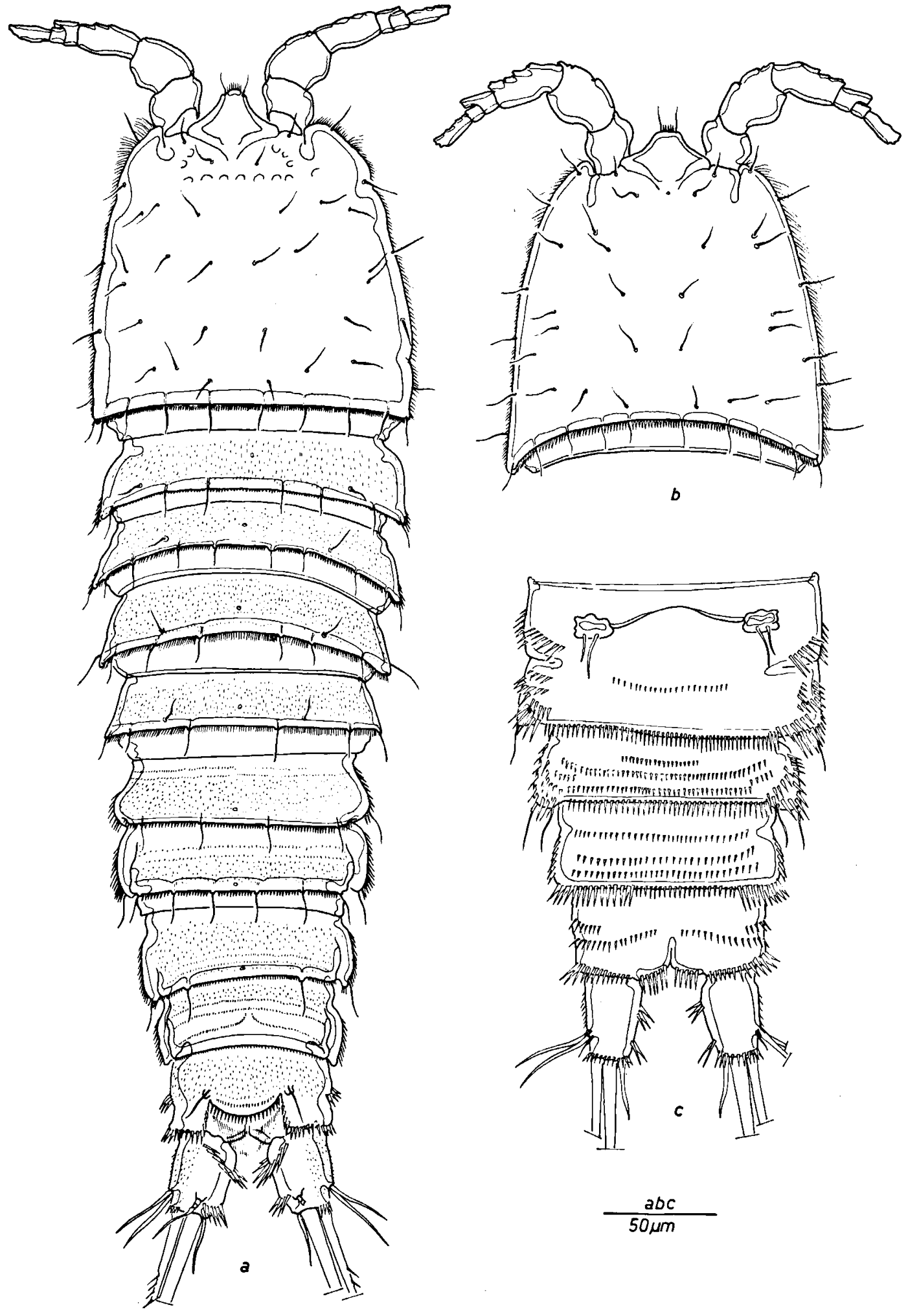

Fig. 13. Lipomelum variabile n. gen., n. sp.: a, habitus of specimen from sta. 80-06; b, cephalothorax of the holotype; $c$, abdomen in ventral view. 


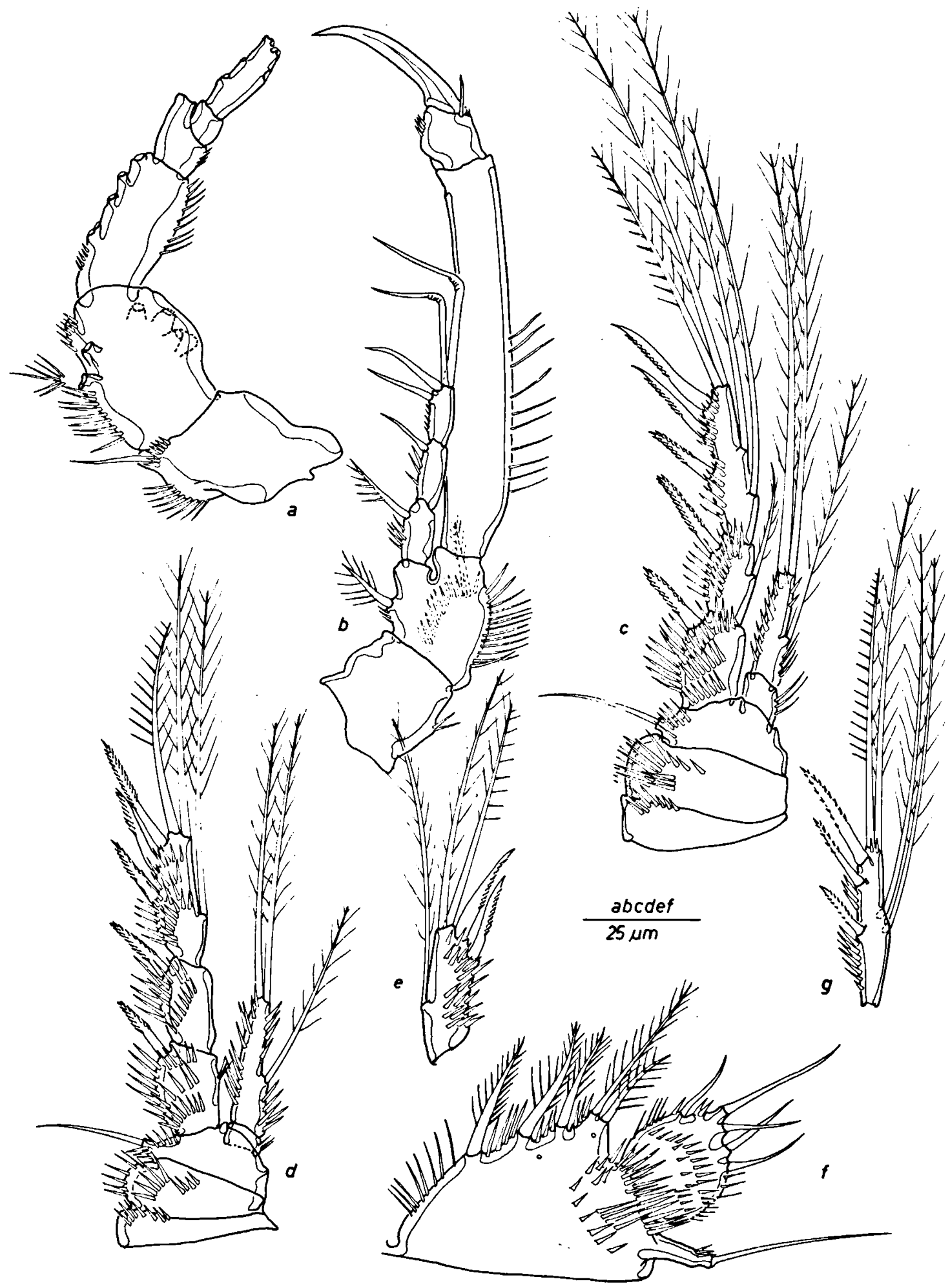

Fig. 14. Lipomelum variabile $\mathrm{n}$. gen., n. sp.: a, antennule; b, P1; c, P3; d, P4; e, ultimate exopodal segment of P4 (other side); $\mathrm{f}, \mathrm{P} 5 ; \mathrm{g}$, third exopodal segment of $\mathrm{P} 2$ (other specimen). 
Mouthparts as in Lipomelum heteromelum $\mathbf{n}$. sp. P1 (fig. 14b): as in L. heteromelum n. sp., but with a slender first endopodal segment (length/width ratio $=6$ ).

P2-P4 (figs. 14c, d, e, and $\mathrm{g}$ ) as in $L$. heteromelum $\mathrm{n}$. sp., but with a different setal formula, cf. tables $\mathrm{V}$ and VI.

\section{TABle V}

Setal formula of Lipomelum variabile n. gen., n. sp.

\begin{tabular}{lccc}
\hline & P2 & P3 & P4 \\
\hline exo & $0-0-123$ & $0-1-1(2) 23$ & $0-0-123(2)$ \\
end & $0-120$ & $0-120$ & $0-120$ \\
\hline
\end{tabular}

\section{TABLE VI}

Variability of the setal formula of Lipomelum variabile $\mathbf{n}$. gen., n. sp. (exopodites only, $\mathrm{L}=$ left, $\mathrm{R}=$ right ramus).

\begin{tabular}{|c|c|c|c|c|}
\hline & & P2 & P3 & P4 \\
\hline \multicolumn{5}{|c|}{ sta. $82-139$ (type-locality) } \\
\hline \multirow[t]{2}{*}{ Specimen $1 \dagger$} & & $0-0-123$ & $0-1-223$ & $0-0-123$ \\
\hline & $\mathbf{R}$ & $0-0-123$ & $0-1-123$ & $0-0-122$ \\
\hline \multirow[t]{2}{*}{ Specimen 2} & L & $0-0-123$ & $0-1-123$ & $0-0-123$ \\
\hline & $\mathbf{R}$ & $0-0-123$ & $0-1-123$ & $0-0-123$ \\
\hline \multicolumn{5}{|c|}{ sta. $78-306$} \\
\hline \multirow[t]{2}{*}{ Specimen 1} & $\mathbf{L}$ & $0-1-123$ & $0-1-123$ & $0-0-123$ \\
\hline & $\mathbf{R}$ & $0-0-123$ & $0-0-123$ & $0-0-123$ \\
\hline \multirow[t]{2}{*}{ Specimen 2} & $\mathbf{L}$ & $0-0 \cdot 123$ & $0-0-123$ & $0 \cdot 0 \cdot 123$ \\
\hline & $\mathbf{R}$ & $0-0-123$ & $0-0-123$ & $0-0 \cdot 123$ \\
\hline \multicolumn{5}{|c|}{ sta. $80-06$} \\
\hline \multirow[t]{2}{*}{ Specimen 1} & L & $0-1-023$ & $0-0-023$ & $0-0-023$ \\
\hline & $\mathbf{R}$ & $0-1-123$ & $0-123^{* * *}$ & $0-0 \cdot 022$ \\
\hline
\end{tabular}

†Holotype; ${ }^{* *}$ two-segmented.

P5 (fig. 14f): baseoendopodite as in $L$. heteromelum $\mathrm{n}$. sp., but with longer spinules on the setae and less teeth on the surface; exopodite somewhat smaller in diameter than in L. heteromelum $\mathrm{n}$. sp.

Male. - Unknown.

Variability. - As table VI shows, L. variabile n. sp. has a very variable setal formula. Especially the presence or absence of an inner seta on the second exopodal segment of P2 is in- constant. Most specimens, however, have a setal formula as specimen 2 from station 82-139 (paratype). One specimen from station 80-06 shows the most remarkable reduction. All other characteristics, however, are identical with the type-species.

Apart from the chaetotaxy of the legs, some variability occurs in the integumental structures of the cephalothorax as well. The holotype (fig. $13 \mathrm{~b}$ ) and the paratypes have an entirely smooth cephalothorax. The specimen from station 80 06 , having an aberrant setal formula, shows a slightly pitted integument in the anterior region of the cephalothorax (fig. 13a).

Discussion. - In spite of the absence of male specimens, Lipomelum variabile $\mathrm{n}$. sp. is assigned to the genus Lipomelum $\mathbf{n}$. gen. because of the following characteristics:

- the prominent rostrum with spinules between the sensillae;

- the six-segmented antennule;

- the proportional lengths of the endopodal segments of $\mathrm{P} 2, \mathrm{P} 3$, and $\mathrm{P} 4$;

- the shape of the baseoendopodite and exopodite of $\mathrm{P} 5$;

- the morphology of the mouthparts which are identical to those of $L$. heteromelum $\mathbf{n}$. sp.;

- the remarkable setal formula of the legs, mainly that of the endopodites.

$L$. variabile $\mathrm{n}$. $\mathrm{sp}$. differs from $L$. heteromelum n. sp. by the depressed body shape, the setal formula of the legs, the antennular process, and the shape of the P4 exopodite of the female.

$L$. variabile $\mathrm{n}$. sp. seems to be closely related to $L$. adriaticum. They show a common habitus and a comparable setal formula of the exopodites. Both species, however, can be discriminated by the different shape of the fifth leg and the chaetotaxy of the endopodite of P2 (0-220 in L. adriaticum and $0-120$ in L. variabile n. sp.).

\section{Klieonychocamptoides itoi Mielke, 1981}

Material. - Amsterdam Expeditions to the West Indian Islands, sta. 82-540. Venezuela (mainland): Río Todasana (further details under Laophonte cornuta). One adult male, in alcohol. 
Remarks. - Mielke, comparing species from the shores of Panama and of the Galápagos Islands, assumed a trans-American distribution of at least some interstitial species (Mielke, 1982). The presence of Klieonychocamptoides itoi Mielke, 1981 clearly supports Mielke's assumption. The distribution of Laophontina triarticulata Coull \& Zo, 1980, and of $K$. itoi illustrates the strong affinities between the east-Pacific coastal fauna and that of the tropical western Atlantic. It also confirms Briggs' (1974: 50) statement that Panamanian species, extending to the Galápagos Islands, have cognate or analogous species in the tropical western Atlantic.

\section{Mexicolaophonte arganoi Cottarelli, 1977 (Figs. 15a-i)}

Material. - Amsterdam Expeditions to the West Indian Islands, sta. 78-229. HAITI, Département du Centre: Plage de l'Amour, Kaloa Beach, along road D 100 at km $58.5\left(18^{\circ} 55^{\prime} 31^{\prime \prime} \mathrm{N} 72^{\circ} 39^{\prime} 27^{\prime \prime} \mathrm{W}\right)$, in interstitia of coarse sand and gravel on a steep beach (intertidal), chlorinity $4640 \mathrm{mg} / \mathrm{l}, 8$ May 1978. Four adult females.

Sta. 78-306. Netherlands Antilles, Curaçao: Boca Tabla (further details under Lipomelum variabile). One female, one male, dissected (slides labelled WIAE 23 and 24).

Remarks. - In most aspects, the specimen studied here agrees with the description given by Cottarelli (1977). Some structures of the West Indian specimens, however, differ somewhat from the original description, but these differences are considered part of the variability of the species. The rather concise description, given below, deals exclusively with the differences observed.

\section{Description}

Antenna (figs. 15a and d) with allobasis, bearing an inner seta implanted at the middle of the external margin; endopodal segment with an additional subapical seta; apical margin with two setae and three adorned spines.

Mandible: as figured by Cottarelli but with four setae and a row of spinules on the mandibular palp.

Maxilla: bearing three endites, the proximal one present as a seta; basis with a seta, im- planted on the hook-shaped process and two setae representing the vestigial rami.

Maxilliped (fig. 15b): basis with a row of spinules; first endopodal segment with some small spinules along the inner margin; endopodal claw with a very small seta only.

P2 of the female (fig. 15c): with a feathered seta on the basis; endopodite and exopodite represented as a seta.

P2 of the male (fig. 15e): almost identical to that of the female; seta of the basis somewhat shorter.

P3 of the female (fig. 15f): first exopodal segment confluent with the basis, bearing an outer spine; second exopodal segment small, carrying two setae.

P3 of the male (fig. 15g): exopodite obsolete, present as a small tubercle with a spine and some small spinules (setae?); endopodite twosegmented; second endopodal segment prolonged and hook-shaped, bearing a small inner seta.

P4 of the female (fig. 15h): almost identical with the figures of Cottarelli, but smaller.

P4 of the male (fig. 15i): second exopodal segment with three setae (spinules?) implanted on the innermost apical edge.

Discussion. - The very remarkable features of the genus Mexicolaophonte fit into the genus group of Laophontina, Pseudolaophonte, Afrolaophonte, and Klieonychocamptoides. All these genera are characterized by their strongly reduced legs and the curious sexual dimorphism in the third leg of the male.

Mexicolaophonte shows most resemblance to the genus Laophontina and mainly to the amphiAmerican species group from which it seems to be derived (Fiers, in prep.).

Apart from $M$. arganoi, a second species was found by Mielke (1982) along the eastern Pacific coast. This species, Laophontina? spec., unnamed and only partly described, clearly belongs to the genus Mexicolaophonte. The typical shape of the third and fifth leg of this male specimen indicate a strong resemblance to $M$. arganoi. Although rather concise, the description of the habitus and the mouthparts of 


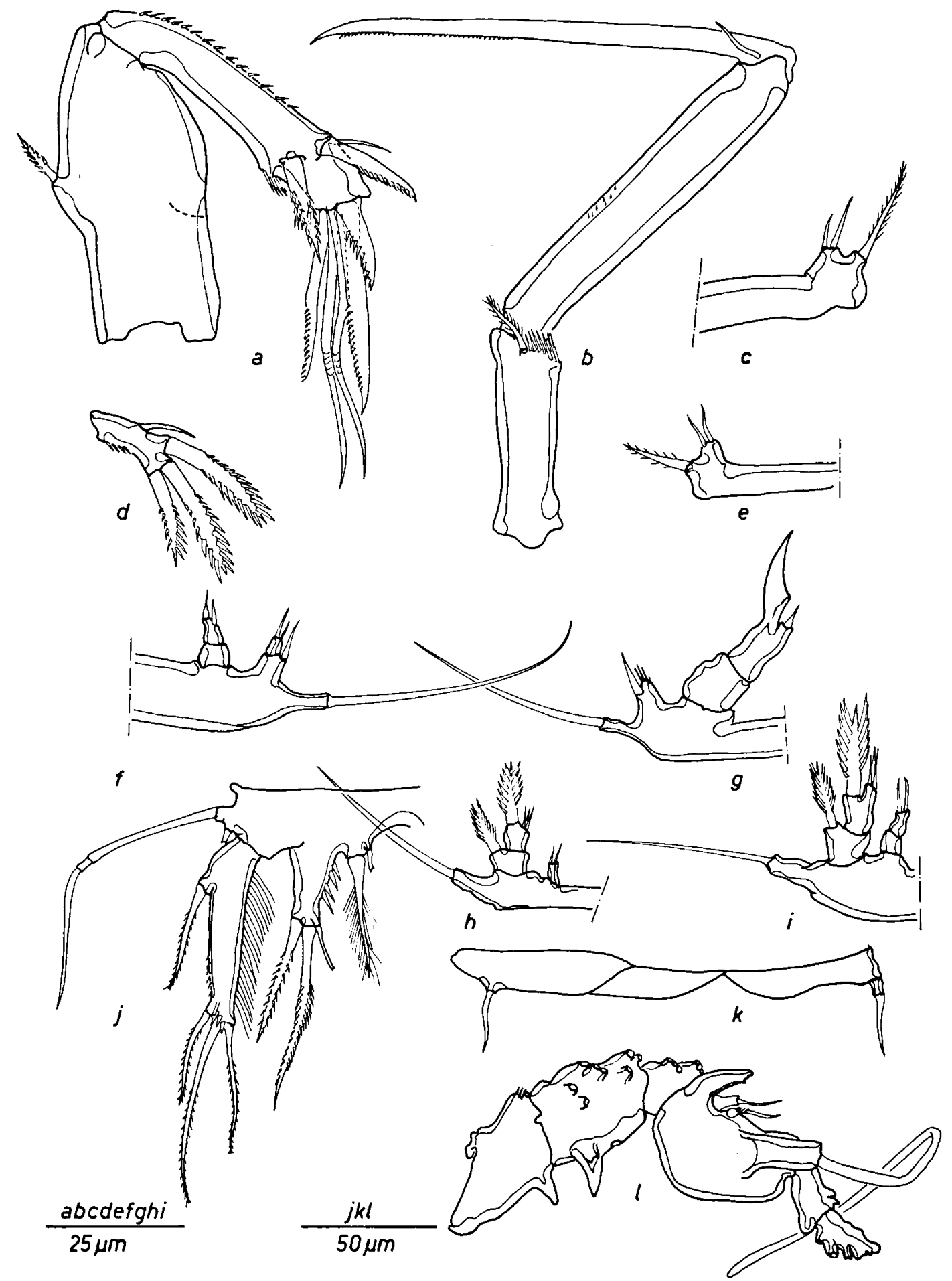

Fig. 15 a-i. Mexicolaophonte arganoi Cottarelli, 1977: a, antenna; b, maxilliped; c, P2 of the female; d, exopodite of the antenna; e, P2 of the male; f, P3 of the female; g, P3 of the male; h, P4 of the female; i, P4 of the male. j-1. Cletopsyllus rotundifera $\mathrm{n}$. sp.: j, P5 of the male; k, P6 of the male; 1 , antennule of the male. 
Laophontina? spec. undoubtedly allows us to assign this species to the genus Mexicolaophonte. Most interesting in Laophontina? spec. are some less derived (plesiomorphic) characteristics: all the legs still have one or two rami, which clearly differentiates it from $M$. arganoi.

\section{Cletopsyllus rotundifera $n$. sp.}

(Figs. 15j-1, 16-18)

Material. - Amsterdam Expeditions to the West Indian Islands, sta. 78-315. Netherlands Antilles, Curaçao: Piscadera Bay (further details under Laophonte plana). One female (holotype) and one male (paratype), both dissected (slides labelled WIAE 19a, b, c and 20a, b, c, respectively).

Etymology. - The specific name rotundifera, from the Latin rotundus (= round) and the Greek фépєıv ( = to bear), alludes to the rounded structure on the baseoendopodite of the female and the round incisions of the hyaline frill of the pleurotergites.

\section{Description}

Female (holotype). - Habitus (figs. 16a and b): length, including rostrum and furcal rami, $1 \mathrm{~mm}$; cephalothorax smooth and with a strongly folded integument; thoracic segments with parallel margins; dorsolateral edges of the thoracic segments strongly elevated; pleurites with smooth surface and sealed with blunt spinules; genital segments fused, fusion marked with a dorsal transversal band; second genital segment and abdominal segments somewhat laterally extended; anal segment without lateral extensions or elevations; anal operculum straight and furnished with long hairs; hyaline frill of the cephalothorax, thoracic and abdominal segments incised, forming robust spatula-shaped lips (fig. 16c); integument of the thoracic and abdominal segments densely covered with an irregular pattern of strong spinules; ventral side of the genital segments (fig. 16e) and the first abdominal segment smooth, except for a small spinulose lateral area; second abdominal segment covered with transverse rows of spinules; median region of the anal segment smooth.
Rostrum (fig. 17e) articulating with the cephalothorax; margins almost straight; tip prominent; integument smooth.

Furcal rami (fig. 16d) flat and about three times as long as wide; outer margin straight; inner margin convex and slightly extended near the apical margin; two external setae, one dorsal seta articulating on two basal parts; principal setae not fused; inner apical seta absent.

Antennule (fig. 17a) four-segmented; each segment bearing strong and adorned setae; first segment with a sharp projection; third segment with an irregularly curved margin; aesthetasc implanted on the third segment and measuring $95 \mu \mathrm{m}$.

Antenna (fig. 17b) with basis; coxa distinctly present; basis with an outer row of strong teeth; exopodite rather small and cylindrical, bearing one seta; second endopodal segment with an outer and a subapical transversal row of slender spinules; two spines and one seta subapically implanted; apical margin bearing three setae and two curved spines.

Mandible (figs. 17c, d): gnathobasis with a row of hairs and a small pars molaris; teeth strongly developed; mandibular palp with a basis and a ramus (exo- or endopodite?); basis having two setae; ramus bearing three apical setae and a subapical one.

Maxillule (fig. 17f): arthrite with seven adorned spines and two setae; surface of the arthrite with a row of long teeth; coxa and basis confluent, each with two setae; endopodite and exopodite obsolete, the former represented by two, the latter by one seta.

Maxilla (fig. 17h): syncoxa with several rows of long and sharp spinules; proximal endite with one long and adorned seta; middle and distal endites each with one adorned spine and two setae; basis prolonged and armed distally, bearing one strong seta; exopodite represented by three setae, endopodite by one.

Maxilliped (fig. 17g): basis short with a strongly curved inner margin, furnished with three rows of long spinules and bearing three feathered setae; endopodal segment with a row of strong teeth; endopodal claw armed distally and bearing a long seta. 


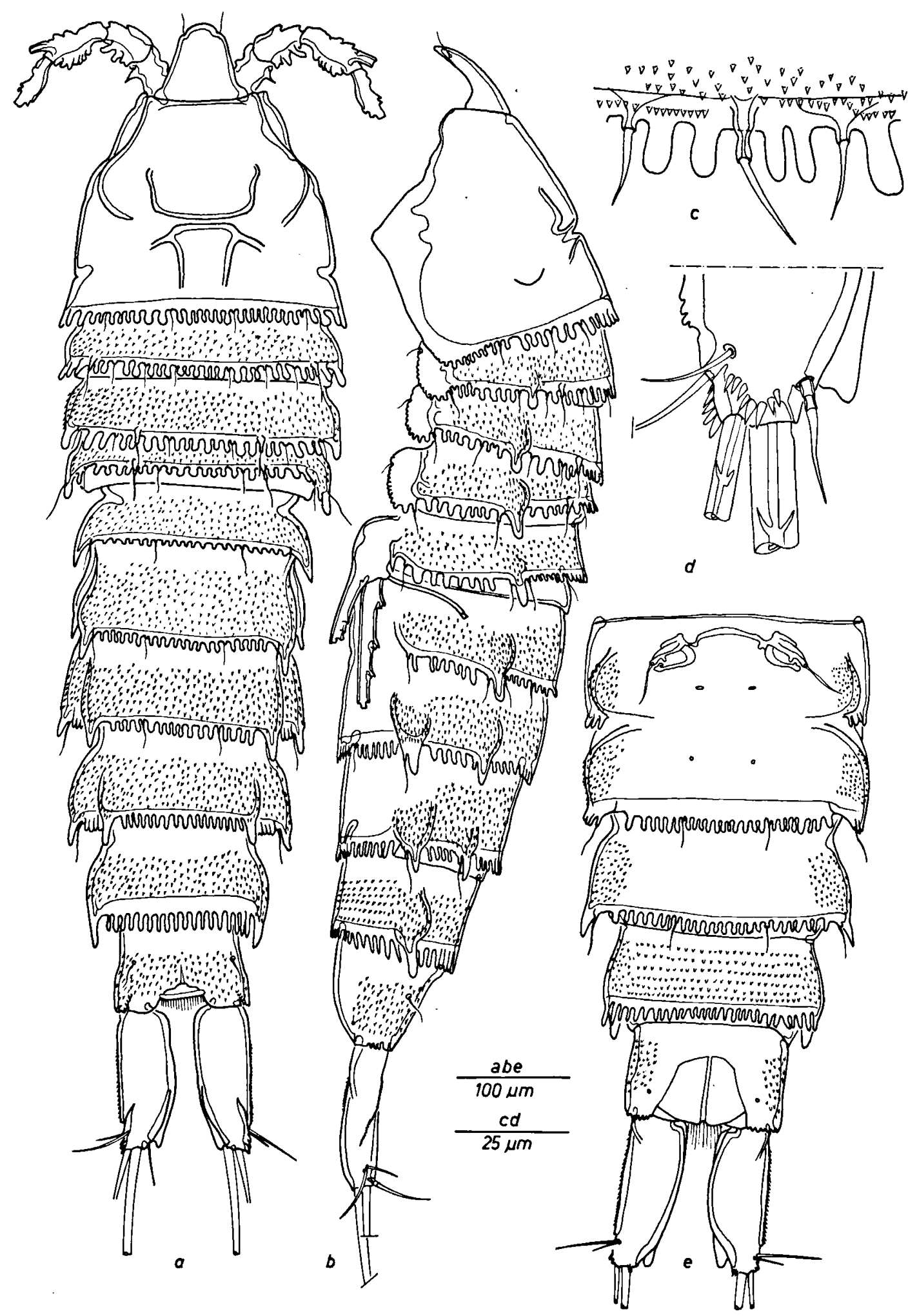

Fig. 16. Cletopsyllus rotundifera $\mathrm{n}$. sp.: a, habitus of the female; b, habitus in lateral view; c, posterodorsal margin of the third pleurotergite; $d$, posterior margin of the left furcal ramus in dorsal view; e, abdomen in ventral view. 


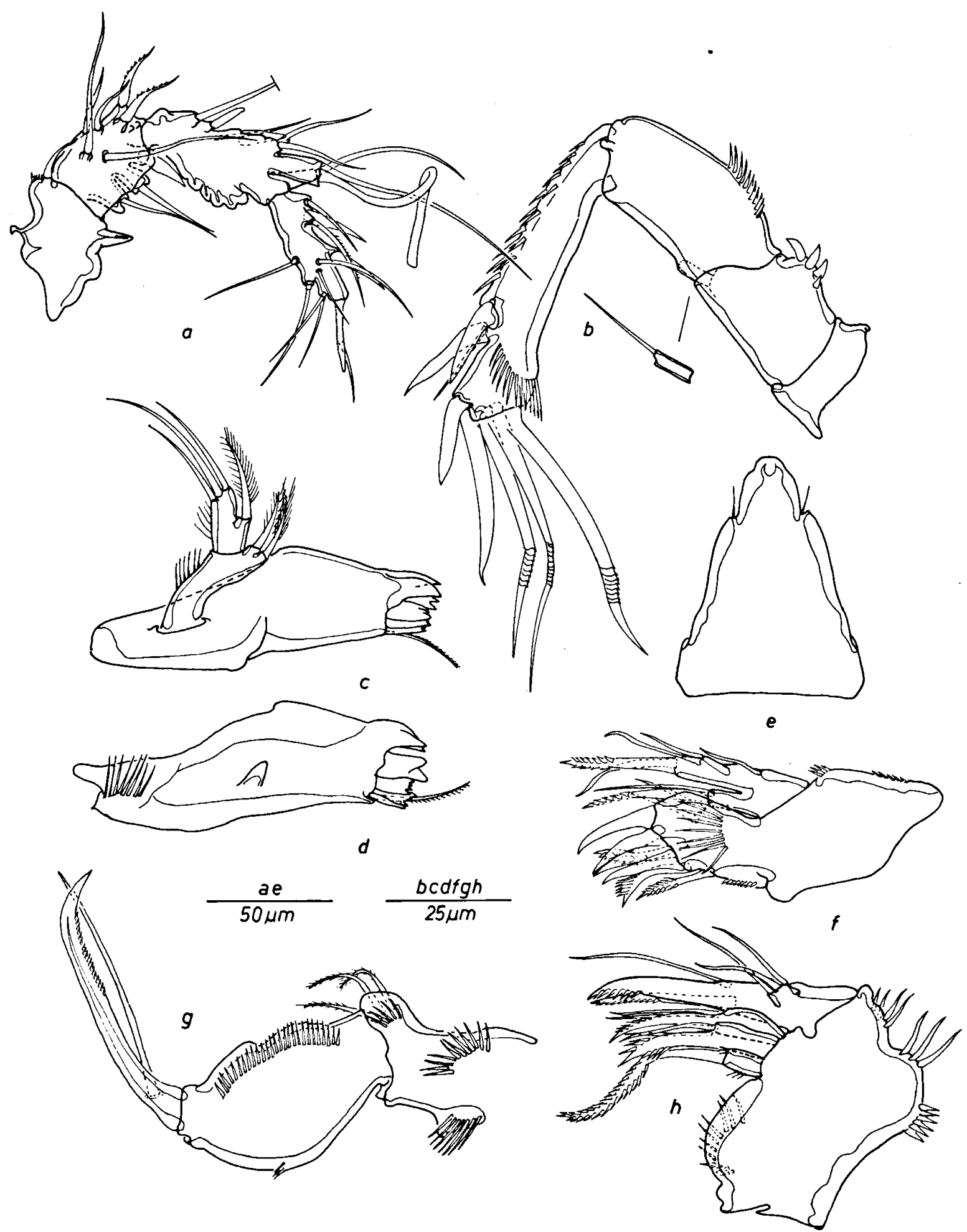

Fig. 17. Cletopsyllus rotundifera n. sp.: a, antennule; b, antenna; c, mandible; d, mandible, opposite side; e, rostrum; $\mathrm{f}$, maxillule; $\mathrm{g}$, maxilliped; $\mathrm{h}$, maxilla. 


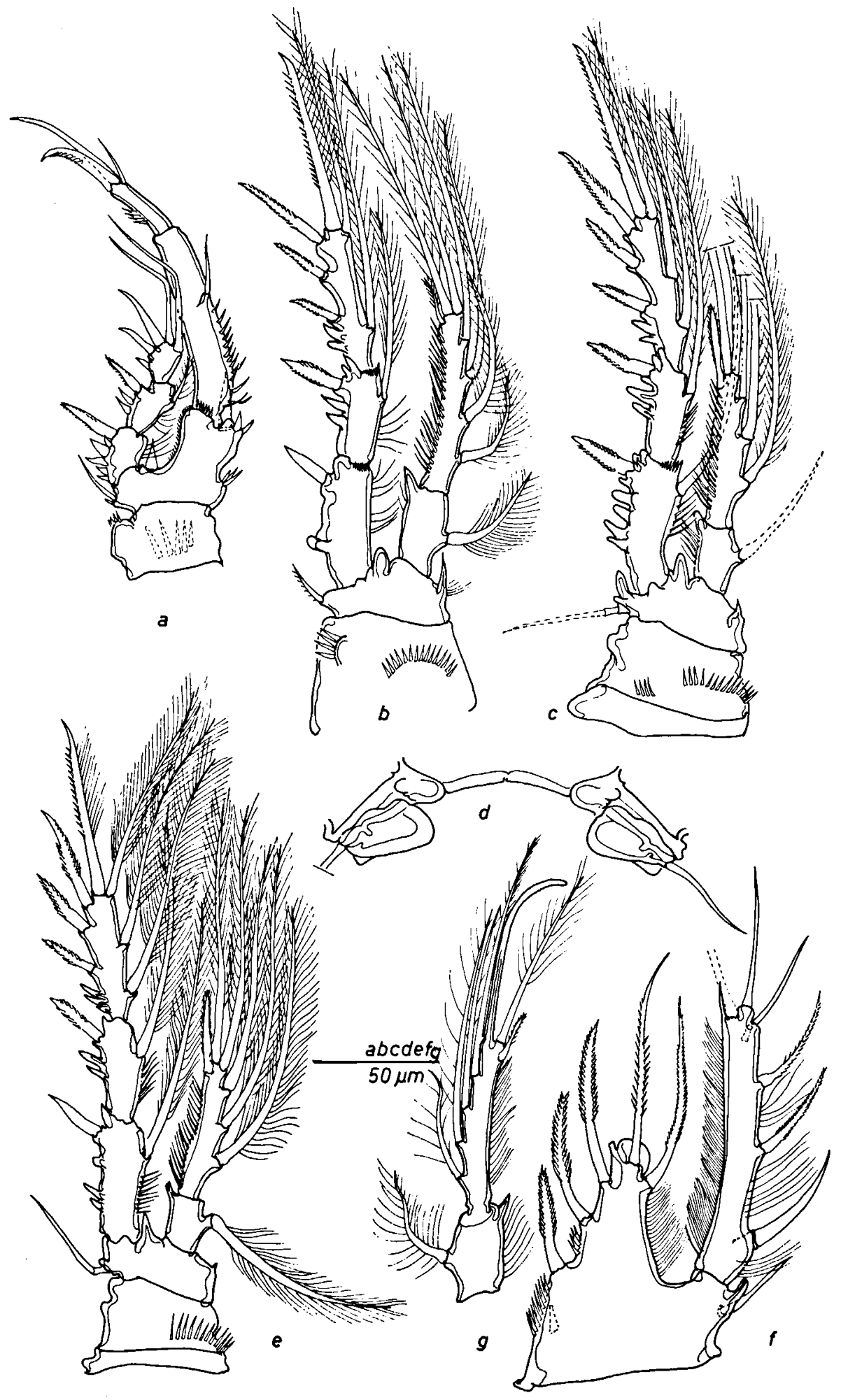

Fig. 18. Cletopsyllus rotundifera $\mathrm{n} . \mathrm{sp} .: \mathrm{a}, \mathrm{P} 1 ; \mathrm{b}, \mathrm{P} 2 ; \mathrm{c}, \mathrm{P} 3$; d, genital field; e, P4; f, P5 of the female; $\mathrm{g}$, inner ramus of $\mathrm{P} 2$ of the male. 
P1 (fig. 18a): coxa with a row of remarkably long spinules; basis with an external seta, an inner apical spine and two rows of teeth along the inner margin; exopodite three-segmented; second segment with an inner seta; endopodite two-segmented; first endopodal segment about four times as long as wide and having an inner seta; second endopodal segment bearing an armed claw and two long setae.

P2-P4 (figs. 18b, c, and e): coxae with rows of spinules; distal margins of the basis with sharp and blunt extensions; outer rami threesegmented, inner rami two-segmented; setal formula shown in table VII; outer margin of the exopodal segments extended in sharp toothshaped processes; inner margin of the exopodal segments and outer margin of the endopodal segments furnished with long setules.

\section{TABLE VII}

Setal formula of Cletopsyllus rotundifera $\mathbf{n}$. sp.

\begin{tabular}{lccc}
\hline & P2 & P3 & P4 \\
\hline exo & $0-1-123$ & $1-1-223$ & $1-1-223$ \\
end & $1-421$ & $1-321$ & $1-321$ \\
\hline
\end{tabular}

P5 (fig. 18f): baseoendopodite with five setae; surface smooth; lateral margins furnished with spinules and hairs; apical margin with a rounded extension; exopodite long, reaching beyond the apical margin of the baseoendopodite; margins fringed with long hairs and bearing six setae; inner apical edge prolonged into a sharp tip.

Male (paratype). - Habitus as the female; length $950 \mu \mathrm{m}$; genital segments not fused; lateral extensions of the genital and abdominal segments absent.

Antennule (fig. 15-l) six-segmented; first segment as in the female; second segment with a sharp lateral extension; aesthetasc $90 \mu \mathrm{m}$ long, implanted on a large socle on the fourth segment; fifth and sixth segment with curved margins.

Mouthparts and legs as in the female except for the second endopodal segment of P2, which bears a long blunt process instead of the inner apical seta of the female (fig. 18g).

P5 (fig. 15j): both baseoendopodites fused in the middle; baseoendopodite prominent, bearing two apical and one proximal setae; exopodite long, reaching beyond the baseoendopodite, having four setae.

P6 (fig. 15k) represented by one seta; left one implanted on a large plate; right one implanted on a small socle.

TABLE VIII

Comparison of $C$. rotundifera n. sp. with related species.

\begin{tabular}{lllll}
\hline & C. rotundifera & C. papillifer & C. secunda & C. bacescui \\
\hline Margin of the 3rd A1 segment & curved & curved & smooth & curved \\
exo of A2 & present & present & absent & present \\
& one seta & two setae & - & two setae \\
exo P1 2nd segment & inner seta & inner seta & inner seta & without seta \\
P5 \& baseoend. apical edge & rounded & sharp & sharp & sharp \\
P5 o baseoend. apical edge & not extended & $?$ & $?$ & sharp \\
P2 $\sigma$ end. & long, blunt & $?$ & $?$ & short, sharp \\
& process & & & process \\
Anal operculum & straight & $?$ & rounded & $?$ \\
& hairy & smooth & spinulose & hairy \\
Length in $\mu \mathrm{m} \%$ & 1000 & 960 & 980 & 1300 \\
Length in $\mu \mathrm{m} \sigma$ & 950 & $?$ & $?$ & 990 \\
\hline
\end{tabular}


Discussion. - Up to now, six species have been attributed to the genus Cletopsyllus. $C$. rotundifera $\mathrm{n}$. $\mathbf{s p}$. in various aspects resembles C. papillifer Willey, 1935, C. secunda Nicholls, 1945, and $C$. bacescui Marcus, 1976. These three species and $C$. rotundifera $\mathrm{n}$. sp. seem to be clearly differentiated from the other members of the genus by their flat and broad furcal rami and by the setation of the fifth leg in the male. C. rotundifera n. sp. and C. bacescui Marcus have four setae on the exopodite of the fifth leg of the male. The other members of the genus, $C$. tertius Por, 1964, C. sagamiensis Ito, 1971, and $C$. brattstroemi Geddes, 1981 show five setae on this appendage and have long and round furcal rami. The shape of the furcal rami and the setation of the fifth leg of the male clearly divide the genus Cletopsyllus in two closely related species groups. Unfortunately, a profound analysis of the relationships between the species is still impossible because information on the males of C. papillifer and $C$. secunda is lacking.

In table VIII the salient features of $C$. rotundifera $\mathrm{n}$. sp. are listed and compared with those of its cognates.

\section{ACKNOWLEDGEMENTS}

I gratefully acknowledge Prof. Dr. J. H. Stock of the University of Amsterdam, who kindly put this copepod collection at my disposal. Special gratitude is extended to Dr. K. Wouters (K.B.I.N., Brussels) for reading the manuscript and to $M$. H. Van Paesschen for drawing the map.

The materials on which this paper is based have been collected in the following regions and by the following members of the Amsterdam team:

1978 - Curaçao, Anegada, Haiti: J. H. Stock, E. S. W. Weinberg, F. Zijlstra.

1979 - Cayman Islands, San Salvador Island, Crooked Island: J. H. Stock, E. S. W. Weinberg.

1980 - Aruba: L. Botosaneanu, J. Notenboom.

1982 - Venezuela: L. Botosaneanu, N. W. Broodbakker, S. E. N. van Lieshout, J. Notenboom, J. H. Stock, M. Stock, E. S. W. Weinberg, F. Zijlstra. 1982 - Jamaica: J. H. Stock, M. Stock.

The fieldwork has been supported by grants to J. $\mathrm{H}$. Stock from the Amsterdamse Universiteits Vereniging (Amsterdam), the Beijerinck-Popping Fonds (Amsterdam), the Fonds Landbouw Hogeschool (Wageningen), the Linnaeus Fonds (Amsterdam), the Netherlands Foundation for the Advancement of Tropical Research (WOTRO, The Hague), and the Treub Maatschappij (Utrecht). This financial support is gratefully acknowledged.

\section{REFERENCES}

Brian, A., 1923. Elenco di Copepodi marini bentonici provenienti da Rovigno e descrizione di una $n$. varietà di Parathalestris clausi Norm. Monitore zool. ital., 34 (7-8): 126-135, pl. I.

BrigGs, J. C., 1974. Marine zoogeography: i-xi, 1-475 (McGraw-Hill, New York).

Chappuis, P. A. \& C. Delamare Deboutteville, 1956. Études sur la faune interstitielle des îles Bahamas récoltée par Madame Renaud-Debyser. I. Copépodes et Isopodes. Vie Milieu, 7 (3): 373-396.

CotTARELli, V., 1977. Mexicolaophonte arganoi n. gen., n. sp. di Laophontidae (Crustacea, Copepoda, Harpacticoida) di acque interstiziali litorali Messicana. In: Subterranean fauna of Mexico, III. Quaderni Accad. naz. Lincei, 171: 91-99.

Coull, B. C., 1970. Harpacticoid copepods from Barbados and Jamaica, W. I., with description of two new species. Caribb. J. Sci., 10 (3-4): 127-133.

- , 1971. Meiobenthic Harpacticoida (Crustacea, Copepoda) from St. Thomas, U.S. Virgin Islands. Trans. Am. microsc. Soc., 90 (2): 207-218.

Douwe, C. van, 1929. Marine Litoral-Copepoden: Zur Verbreiting des Genus Laophonte Philippi im Mittelmeer. Zool. Anz., 83 (11-12): 283-294.

Fiers, F., 1984a. Allocation of Paralaophonte spinicauda Vervoort (Copepoda, Harpacticoida) to the genus Laophonte. Crustaceana, 46: 317-319.

- , 1984b. Harpacticoid copepods from the West Indian Islands: Canuellidae and Longipediidae (Copepoda, Harpacticoida). Bijdr. Dierk., 54 (2): 197-210.

Jakubisiak, S., 1933. Notes sur les Harpacticoïdes de l'Adriatique. Fragm. faun. Mus. zool. Pol., 2 (11): 113-116.

LANG, K., 1948. Monographie der Harpacticiden, 2: 8991682 (Håkan Ohlsson, Lund).

-, 1965. Copepoda Harpacticoidea from the Californian coast. K. svenska VetenskAkad. Handl., (4) 10 (2): 1-560, pls. I-VI.

MielKE, W., 1981. Interstitielle Fauna von Galapagos XXVIII. Laophontinae (Laophontidae), Ancorabolidae (Harpacticoida). Mikrofauna Meeresbodens, 84: 1-104.

- , 1982. Einige Laophontidae (Copepoda, Harpacticoida) von Panama. Crustaceana, 42: 1-11.

Petkovski, T. K., 1955. Zweiter Beitrag zur Kenntnis der . Harpacticidenfauna unserer Meeresküste. Fragm. Balcan., 1 (15): 125-139. 
Vervoort, W., 1964. Free-living Copepoda from Ifaluk Atoll in the Caroline Islands with notes on related species. Bull. U.S. natn. Mus., 236: i-ix, 1-431.

Wells, J. B. J. \& K. G. McKenzie, 1973. Report on a small collection of benthic copepods from marine and brackish waters of Aldabra, Indian Ocean. Crustaceana, 25: 133-146.

Wells, J. B. J., G. R. F. Hicks * B. C. Coull, 1982. Common harpacticoid copepods from New Zealand harbours and estuaries. New Zeal. J. Zool., 9:
151-184.

Wilson, C. B., 1936. Copepodes from the cenotes and caves of the Yucatan peninsula, with notes on Cladocerans. Publs. Carnegie Instn., 457: 77-88.

Yeatman, H. C., 1962. The problem of dispersal of marine littoral copepods in the Atlantic Ocean, including some redescriptions of species. Crustaceana, 4: 253-272.

- 1976. Marine littoral copepods from Jamaica. Crustaceana, 30: 201-219.

Received: 17 June 1985 